\title{
USING HALLUCINOGENS WITH INJECTION TECHNIQUE IN THE NOVEL "QUANTUM QODE" AND SOME MIND CONTROL METHODS
}

\section{Pelin Dimdik Emeksiz *}

* İstanbul Üniversitesi

E-mail: pelindimdik@hotmail.com

Copyright (C) 2016 Pelin Dimdik Emeksiz. This is an open access article distributed under the Eurasian Academy of Sciences License, which permits unrestricted use, distribution, and reproduction in any medium, provided the original work is properly cited.

\begin{abstract}
Directing a variety of ways beyond the will and the desire of a person is called mind control. There are many different methods for controlling human mind. Minds are controlled by means of hallucinogens and fatal consequences of this method are exhibited in novel "Quantum Code". The novel describes how could be a dangerous weapon if the mind control is captured by some dark organizations and persons. Both personal ambitions and interests as well as the effects of bad results originated from competition of basis of government and institution create highly damaging effects for humanity creates. It is unquestionable fact that persons and groups, who use mind control techniques to damage the humanity and the community, to obtain benefits and to satisfy the ego, have real and serious mental health problems. Being aware of mind control methods will reduce the expected impact on the person. In this regard, the relevant article was written for the purpose of providing information about some mind control methods based on a literary work.
\end{abstract}

Keywords: Kuantum Şifresi, Psychiatry, Mind Control, Hallucinogen, Hypnosis

\section{“KUANTUM ŞIFFRESİ" ROMANINDA HALÜSINOJENLERİN ENJEKSIYYON TEKNİĞIYYE KULLANIMI VE BAZI ZİHİN KONTROL YÖNTEMLERİ}

\section{ÖZET}

Bireyin zihninin kendi istek ve bilgisi dışında çeşitli yollarla yönlendirilmesi zihin kontrolü olarak adlandırılmaktadır. İnsan zihnini kontrol etmenin çok değişik yöntemleri mevcuttur. "Kuantum Şifresi" romanında zihinler, halüsinojenler vasitasıyla kontrol edilmekte ve bu yöntemin ölümcül sonuçları sergilenmektedir. Romanda zihin kontrolünün birtakım karanlık örgütler ve kişilerin elinde nasıl tehlikeli bir silaha dönüşebileceği anlatılmaktadır. Gerek kişisel hırs ve çıkarların etkisiyle gerekse devletler ve kurumlar bazındaki rekabetin kötü sonuçları insanlık için son derece zarar verici etkiler yaratmaktadır. Zihin kontrol yöntemlerini insana veya insan topluluklarına zarar verme, menfaat elde etme, ego tatmini sağlama gibi 
niyetlerle uygulayan kişi ya da grupların çok ciddi akıl sağlığ problemleri olduğu tartışılmaz bir gerçektir. Zihin kontrol yöntemlerinin farkında olmak onların birey üzerindeki istendik etkisini azaltacaktır. Bu bakımdan ilgili makale bir edebi eserden hareketle bazı zihin kontrol yöntemleri hakkında bilgi verme amaçlı olarak yazılmıştır

\section{Anahtar Kelimeler: Kuantum Şifresi, Psikiyatri, Zihin Kontrol, Halüsinojen, Hipnoz}

\section{Giriş}

Zihin kontrolü, psikolojik yöntemleri iyi bilerek kullanan siyasi partilerin, kültlerin, tarikatların, cemaatlerin veya istihbarat örgütlerinin uyguladıkları bir tekniktir. İnsanın zihnini kontrol etmenin çok çeşitli yöntemleri bulunmaktadır. "Bu yöntemin temelini bireyin veya insan gruplarının davranışlarını değiştirmek ya da kontrol etmek maksadıyla isteği ve bilgisi haricinde uygulanan bireysel ve toplumsal zihin kontrolü, propaganda, psikolojik faaliyet, kimyasal maddeler", elektromanyetik dalgalar, gazlar (Sayın, 2007: 53) gibi çeşitli unsurlar oluşturmaktadır.

İnsanoğlunun topluluk halinde yaşamaya başladığı dönemden itibaren toplumsal hafizalar ve bireylerin düşünceleri kesintisiz olarak kontrol altına alınmak istenmiştir. Klanın ortaya çıkış sürecini dikkatlice incelediğimizde ilk kültlerin klanlar olduğu bilgisine ulaşırız. Bireyin fikir hürriyetinin belirgin bir biçimde elinden alındığı klan, yerini feodal topluma, sonra da modern topluma bırakmıştır. (Yörükoğlu, 2012: 111)

Bireyleri topluluk halinde beyin kontrolüne tabi kılan egemenler, kitlesel kontrolün de ötesinde bireysel kontrole yönelirler. Bunun için egemenlerin çıkarlarına en iyi hizmet edecek ve onlara itaat eden hedef kişiler belirlenir ve her birine farklı formatlarda beyin kontrolü uygulaması yapılır. Ve bu kişiler, belirli bir süre sonra tamamen kontrol altına girip istenilen amaçlar doğrultusunda sanatsal, akademik ortamlarda, güvenlik teşkilatlarında ve daha pek çok yerde faaliyet göstermeye başlarlar. Beyin yıkama yöntemi başlangıçta uygulama olarak zor gibi görünse de aslında metodun devam ettirilebilirliği aynı oranda kolaydır. Eğitim sistemleri ve 'devlet organları' dünyada en etkili beyin yıkama operasyonunu idame ettirmektedirler. "Eğitim sistemine teslim olmuş, onu sorgulamayan ve devlet organları ile onların uzantılarını birer 'mit' olarak gören toplumlarda beyin yıkama teknikleri oldukça basit ve fazla enerji gerektirmeyen yöntemlerdir." Eğitim sistemi ve "kutsal" devlet kurumları tarafından beyni kontrol edilen birey bir süre sonra genetik davranışları ile şiddetli bir çatışma içine girer. Genetik bir davranışın unutulabilmesi için üzerinden 200 yıl geçmesi gerekmektedir. Ancak toplumsal bağlamda bu davranışların unutulması mümkün görülmemektedir. Çünkü biyo-psiko-sosyal bir varlık olan insanın tutum ve davranışları nesilden nesile miras yolu ile aktarılmaktadır. Genetik davranışları ile şiddetli çatışma yaşayan beyni yıkanmış birey, içsel tatmini sağlamak adına bir arayış içine girer. Bu durum kişiyi eğlenmek için çeşitli faaliyetlere, "sosyal çevre veya sınıf değiştirmeye, dine yönelmeye, dinden veya toplumdan kaçışa sürükler”. (Şimşek, 2005: 10-11)

Esasında insan beyni sürekli olarak kontrol altındadır. Kontrol altına alınmadığı dönem yoktur. Beyin dışardan ve içerden gelen stimuluslara ve algılara çok açıktır. Dışarıdan gelen algılarla beyni kontrol etmek mümkündür. Zaten toplumsal beyin kontrolü her zaman var olmuştur. En dikkat çeken örneği Hitler'dir. Hitabet sanatını ve diğer teknikleri çok iyi kullanarak insanların zihinlerini kontrol etmiştir. Ayrıca bugün psikiyatrların ve psikologların da yaptığı budur. Yani insanların beynini kontrol etmek. (Sayın, 2007: 53,69) 


\section{Psikolojik Savaş}

Bireyin ve toplumun duygu ve davranışlarını inceleyen psikoloji, elde ettiği bilimsel verilerinden hareketle hedef olarak seçilen yahut düşman gibi görülen kişi ve kitlelere karş1 da kullanılmaktadır. Bu faaliyetlerde, psikolojik savaş kavramı içindeki propaganda, yıldırma, inandırma gibi metodlar uygulanmaktadır. (Bahar, 2009: 23) Psikolojik savaş, çeşitli zihin kontrolü yöntemlerini içine alan geniş bir kavramdır. Psikolojik savaş, insanların beyninde ve toplumun psikoloji üzerinde sürdürülen savaştır, hedefi 'gerçek olmayan' birtakım yanlış bilgi ve olayları "propaganda, zihin kontrolü, medyanın kontrolü, toplu telkin ve beyin yıkama ile 'gerçekmiş gibi' göstermektir. Böylece düşmanın ve karşıt güçlerin beyninde ve psikolojik tabanında da savaşın kazanılması hedeflenmektedir." (Sayın, 2007: 81)

Psikolojik savaşın birinci aşaması, düşmanını ve kendini iyi tanımaktır. İkinci aşama, baskı ve ikna tekniklerini kullanarak karşı tarafta psikolojik çöküntüye yol açmaktır. "Psikolojik savaşın saldırı ve savunma silahı; propaganda, eğitim ve provakasyondur." Cephesi ise; söz, yazı, resim, broşür ve radyo, televizyon, bilgisayar gibi iletişim araçları aracılığıyla yayılan bilgilerdir. Bu savaş yönteminin amacı, insanları ikna etmek ve onlarda düşünce, duygu ve davranış değişikliği yaratmaktır. Yöntemi ise beyin yıkamadır. (Simşek, 2005: 126)

\section{Propaganda ve İletişim Araçları}

İdeal anlamda masumiyet içermesi gereken propaganda kavramı, kullanım amacı ve kullananların niyeti bakımından şimdiye kadar kötü bir ün yapmış ve sosyal bir anlam ifade etmekten ziyade siyasi bir çizgi yol almıştır. Öyleki bu kavram, onu kulananların elinde bir sosyal yaklaşım vasıtası olmaktan çok, sosyal felaketlerin menşesi olmakta ve bir beyin yıkama yöntemi şeklinde kullanılmaktadır.(Bahar, 2009: 120)

Propaganda amacını gerçekleştirmek için yani insanın duygu, düşünce ve davranışlarını etkilemek veya değiştirmek maksadıyla birtakım iletiler, simgeler kullanmaktadır. Bu unsurları yaymak için de çeşitli kanallara ihtiyaç duyar. Farklı niyetlerle hazırlanan propaganda mesajlarını hedefe ileten bu kanallar haberleşme araçları olarak adlandırılmaktadır. Haberleşme araçları mesaj dağıtım yöntemlerine göre dört kategoriye ayrılmıştır. Yüz yüze haberleşme; mitingler, gruplar, sosyal faaliyetler ve kişisel temaslar yüz yüze haberleşme ortamlarındandır. Göze hitap eden haberleşme araçları; çizgi filmler, resim veya slaytlar, broşür, gazete, afiş, bildiri, kitap, dergi, risale gibi basılı araçlar, tuhafiye, biblo ya da üzerine mesaj basılabilen herhangi bir parça eşya gibi basılı ürünlerdir. Kulağa hitap eden haberleşme araçları; en yaygın olanı radyodur. Hem göze hem kulağa hitap eden haberleşme araçları; en başta gelenler televizyon, sinema ve internettir. (Şimşek, 2005: 136-137) "Toplumsal zihin kontrolü maksadıyla, görsel ve işitsel iletişim araçları; yazılı ve basılı materyaller gibi pek çok araç-gereç kullanılmaktadır. Bunlar vasıtasıyla toplumun kafasına işlenen pek çok motifle, düşüncelere istenilen doğrultuda yön verilmektedir.” (Sayın, 2007: 53)

\section{Fikir, İdeoloji Aşılama}

Cemaat, tarikat, ideolojik parti vb. gibi adı ne olursa olsun, bireyi kontrol altına alıp onu kişisel egolarının ve çıkarlarının tatmini için kullanan lider, beyin ve davranış kontrolünden sonra bireyin bilgi edinme ve haber alma kaynak ve standartlarını da belirler. Buradaki maksat, kişinin tüm benliğinin yanında geleceğinin ve düşlerinin bile ele geçirilip kültün çıkarına sunulmasıdır. Bilgi kontrolündeki 
diğer hedeflerden biri de bilgiye ulaşımı ve bireyin bilgiyi işleyişini kontrol ederek kişinin grup faaliyetlerine yönelik olumsuz yorum yapmasına engel olmaktır. Bilgi kontrolü, birey külte dahil olduğu sırada, kişi yanlış bilgilendirilip ikna edilerek başlar. Katılımın gerçekleştiği süreden itibaren aldatma süreci çok yoğun işletilir(Yörükoğlu, 2012: 115)

"İnsanlar külte katılmazlar, kült onları seçer. Grup dışındaki bilgi kaynaklarına erişimi en aza indirgeme veya caydırma, grubun kitapları dışındaki kitaplar, makaleler, gazeteler, dergiler, TV, radyo yasaklanabilir ya da sınırlı hale getirilir. Ayrılan eski üyelerle görüşmek kesinlikle yasaktır. Biz ve onlar görüşü hakimdir. İçerisine ve dışarıya ait bilgiler vardır. Farklı hiyerarşik seviyedeki insanlar farklı bilgiler alırlar. Lider kimin neyi bilmesine karar verir. Diğer üyeler ile ilgili casusluk yapmak teşvik edilir. 'Şahit' ya da 'buddy' sistemi ile çift yapıp gözlemek ve kontrol etmek. Grup tarafindan üretilen bilgi ve propagandanın ileri derecede kullanılması. Gazeteler, dergiler, günlükler, ses kasetleri, video kasetler... Yıkıcı zihin kontrolünün ancak bu dört bileşeninin genel etkisi, bir lidere veya bir amaca bağımlılığa yol açması halinde var olduğundan söz edilebilir. Listedeki her bir maddenin mevcut olması gerekmez. Zihni kontrol altında grup üyeleri kendi dairelerinde yaşayabilirler, sabah 9'dan akşam 5'e kadar bir işte çalışabilirler. Lider, müridin duygularının limitlerini yönetir ve daraltır, eğer herhangi bir problem olursa, asla liderin veya grubun değil de kendi hatasından ötürü olduğunu hissetmesini sağlarlar, suçluluk duygusunu aşırı derecede kullanırlar. Kişi potansiyelini tam olarak kullanmamasından, ailesi, geçmişi, yakınları, düşünceleri, duyguları, hareketleri veya geçmişteki devamlı karşısına yapmış olduğu büyük suçlar olarak çıkarılır. Kült yapılarında korku devamlı kullanılır. Dış dünya korkusu, düşman korkusu, grup tarafından dışlanma korkusu. Tüm bu korkular verilirken suç sayılmayacak konular bile büyük günah gibi toplum önünde itiraf ettirilir. Fobi telkini çok yoğundur grubu terk etmeye veya liderin otoritesini sorgulamaya bile duyulan irrasyonel korkuların programlanması... Zihni kontrol altında bir insan grup dışında pozitif ve dolu bir geleceği gözünde canlandıramaz. Grup "dışında" mutluluk veya tatmin yoktur. Ayrilırsanız korkunç şeyler olur, 'dışarıdaki hayat tek başınıza sizi yutar', 'şeytanın esiri olunur', 'kötü yola düşülür', 'iyileşmeyen hastalıklar olur', "kazalar', 'intiharlar', 'delilik', vs. Ayrılmak için asla geçerli ve mantıklı bir sebep yoktur."(Şimşek, 2005: 13-15)

Beyin yıkama veya fikir aşılama uygulamalarının en dikkat çeken yönü, bu uygulamaların gerçekleştirildiği ortam terk edildiği andan itibaren, söz konusu metotların meydana getirdiği ideolojik etkinin gücünün kaybolmasıdır. "Dolayısıyla herhangi bir ideoloji veya din, ferdin şahsiyet yapısına bağlı olan ve şimdiye kadar şuuraltında gizlenen eğilimlerle uyuşmadığı sürece, o ideolojiyi empoze edenin veya din adamının varlığı ile kaimdir.”(Brown, 2012: 247)

\section{Bilinçaltı Mesaj}

“20. yüzyılın ikinci yarısında uygulanan başka bir medya stratejisi de mesajları bilinçaltına yerleştirmektir. İletişim yoluyla bilinçaltına mesaj aşılamanın birçok yöntemi vardır. Elektronik medyanın başvurduğu tekniklerden bazıları duyu eşiği altı ses, geçmişe gizleme, tachististopic flaşlar, imaj eşleştirmeleridir. Yazılı basınsa en çok gömülü mesajları, imaj eşleştirmelerini ve sembolizmi kullanır."(Keith, 2006: 52)

\section{Hipnoz}

Hipnoz çok eski bir sanattır. İlk defa Hristiyanlık ortaya çıkmadan önce büyücülük, din ve tıp bir aradayken kullanılmıştır.(Bahar, 2009: 215) I. Dünya Savaşı'nda hipnoz casusluk amaçlı 
kullanılmaya başlanmıştır. 1920’lerde Colgate Üniversitesi Psikoloji Bölüm Başkanı Dr. George Estabrooks, hipnoz ve insanların iradelerinin kontrolü üzerinde çalışmıştır. Estabrooks'un ilk keşiflerinden biri de çoklu kişiliğe sahip bireylerin tedavisinde kullanılan hipnozun, bireye birden çok kişilik kazandırmak maksadıyla kullanılabileceğidir.(Keith, 2006: 82) Daha önce farklı bilinç hallerine vakıf olmayan kişilerde tanınmadık bir bilinç hali meydana gerirerek bilincin kontrolünü zayıflatmak ve bilinç dışının ortaya çıkmasını sağlamak mümkündür. Böylece hiçbir iz bırakmadan hatta kişinin kendisinin bile farkında olmayacağı bir şekilde ondan bilgi almak olasıdır.(Sayın, 2007: 72)

Hipnoz gerçekte zannedildiğinden daha tehlikeli bir yöntemdir. Her ne kadar bilimsel kitaplarda, hipnozla insana iradesinin dışında bir eylem yaptırılamayacağı iddia edilse de son zamanlarda bunun doğru olmadığına yönelik birtakım düşünceler mevcuttur. Yani bir insanın hipnozla isteklerinin dışında bir eyleme yöneltilebileceği, örneğin cinayet işletmek gibi, iddia edilmektedir. Hipnozda birey normal bilinciyle hatırlamadığı ve kontrolünü bir başkasının eline aldığı farklı ve telkine açık bir bilinç haline girmektedir. Özellikle hipnoz öncesinde veya sonrasında verilebilecek birtakım kimyasal maddeler hipnozun etkisinin artmasını sağlayabilmektedir. Hipnoz altındaki kişi öyle yönlendirilebilir ki, kişi kendisini bir kahraman olarak görebilir ve istenen eylemleri harfi harfine yerine getirebilir, özellikle ilaçlandığında.(Sayın, 2007: 153,159)

Beyin kontrolü hipnoz, düşünceyi durdurma ve düşünceyi yönlendirme gibi belli yöntemleri ve teknikleri içerir. Bu yöntem ve teknikler, kişilerin nasıl düşünmesi, hissetmesi ve davranması gerektiğini belirler. Bu uygulama etik temele dayandığı takdirde zararlı değildir. Fakat bir liderin, istediklerini elde etmek amacıyla bu yöntemleri kullanarak kişileri kendine bağımlı köleler yaratması durumu çok tehlikelidir. Zihin kontrol yöntemleriyle bireyin gerçek benliği, davranışları, düşünceleri, hisleri baskı altına alınır ve yeni bir kişilik oluşturulur. Zihin kontrolü yöntemlerini tanımayan onlardan haberdar olmayan bir kişinin bu yöntemlerle başa çıkma şansı pek yoktur.(Yörükoğlu, 2012: 113)

Bu beyin yıkama yöntemleri rejime muhalif insanlar üzerinde uygulandığı gibi rejim yanlısı olan insanların rejim ile tam bir uyum içerisinde tıpkı birer robot gibi çalıştırılabilmesi amacıyla da uygulanmaktadır. Gönüllü hipnoz gibi çeşitli seanslar yoluyla bilinç dışına girilen savunmasız kişi rejimin tam bir robotu olabilmektedir. Tüm düşünce kalıpları rejimin istediği insan tipini ortaya çıartmak yönündedir. Dolayısıyla bireyin gerektiği zaman bir terrorist ya da bir sabotajcı gibi eğitilmesine imkan vermektedir.(Şimşek, 2005: 17)

\section{Kimyasal Maddeler}

Gerek kimyasal ajanlar gerekse başka vasıtalarla amaçlanan şey, insanın normal algı düzeyini değiştirip ona 'farklı bilinç halleri' yaşatmak ve kişi bu durumdayken yapılan telkinlerle onu bilinçdışı eylemlere yönlendirebilmektir. 'Farklı bilinç halleri' gerçekte insanların uzak olmadığı bir durumdur. "Rüya görme hali, hipnotik bilinç hali, ekstazi(esrime) meditasyon ve yoga ile varılan bilinç halleri, anestetik maddelerle varılan bilinç halleri(pentotal, fenobarbital, halotan), duyusal yoksunlukla ulaşılan bilinç halleri, halüsinojenlerle varılan bilinç halleri (LSD-25, meskalin, PCP, MDMA vb) ve keşfedilmemiş tüm bilinç hallerini kapsayan çok geniş bir terimdir.” Farklı bilinç hallerinde kişiler telkine açık hale gelirler, illüzyonlar görürler. Bunların gerçek olduğuna, kendilerinin seçilmiş olduğuna, bu dünyada bir görevlerinin olduğuna varıncaya kadar pek çok şeye inandırılabilirlerse, normal bilinç durumunda yapamayacakları birçok şey onlara bu durumdayken yaptırılabilir. (Sayın, 2007: 67,68,71) 


\begin{tabular}{|l|l|l|}
\hline 6 & & $\begin{array}{l}\text { "Kuantum Şifresi” Romanında Halüsinojenlerin Enjeksiyon Tekniğiyle Kullanımı ve Bazı Zihin } \\
\text { Kontrol Yöntemleri }\end{array}$ \\
\hline
\end{tabular}

Sentezlendiği tahmin edilen 2000'e yakın halüsinojen ve binlerce draje ilaç vardır.(Sayın, 2007: 75) "Derin Devletler Gizli Projeler Kirli Gerçekler" adlı kitabın yazarı Doç. Dr. Ümit Sayın insan bilincini etkileyen bu kimyasalların bazılarından bu çalışmada bahsetmiştir. Aşağıda eserde adı geçen birtakım kimyasallar ve etkilerini verilmiştir:

"Esrar (THC), sodium pentotal gibi bir çok madde bireysel zihin kontrolü amaciyla kullanılmıştır. THC'nin etkisinde bilinç dışına ait çeşitli bastırılmış motifler, imajlar ortaya çıkar. Güçlü halüsinojenler olan LSD, MDA, STP, Mescalin, PCP, İbogain algılanmakta olan her şeyin distorsiyona uğramasına, renklerin, seslerin veya bilinç dışından gelen her türlü düşüncenin değişmesine yol açar. Bu gibi diğer ilaçlarla bir kült içinde insanı trans haline sokmak ve istenilen amaçlar doğrultusunda kullanmak mümkündür. Sodyum pentotal, kemo-hipnoz yapmaktadır ve bunu insanları konuşturmak için kullanmışlardır. Gerçekten kimyasal ajanlar kullanılarak yapay anksiyete, hipnoz, rüya görme hali, ağrıya duyarlılığın artması veya azalması, hafıza kaybı veya hatırlatma, sersemlik, psikoz, yaratıcı düşünce veya aşırı duyarlılık oluşturulabilir.” (Sayın, 2007: 54)

Örneğin kimyasal zihin kontrolü operasyonlarında mistik birtakım deneyimler yaşadıklarını iddia eden kişilerin temelde hissettikleri duyumlar aşağıdaki gibi sıralanabilir:

"Zaman algisinin degismesi (LSD, THC, İbogain vb. veya psikoz), Güçlü bir mistik deneyim (LSD, Psilosibin, Meskalin vb. veya mistik psikoz), Melekler ve Allah veya Saidi Kürd-i veya Seyh ile konuşmak (LSD, psilosibin vb. veya psikoz), Cisimlerin boyutlarında degişiklik (LSD veya diger halüsinojenler veya psikoz), Ses duymak (temporal bölgede etkisi güçlü halüsinojenler veya psikoz, sizofreniform reaksiyon, psikozda ve sizofrenide en sık görülen ses duymadır.), Ortamın aydınlanması, farklı ışıkların görülmesi, yazıların veya duvardaki resimlerin canlanması (LSD veya psilosibin, PCP veya psikoz), Kendini cok yetkin hissetmek, gorevi oldugunu ve Tanrı tarafından bir görevle görevlendirildigini düşünmek (yüksek doz metamfetamin, LSD, DOM, Psilosibin, Meskalin vb.veya Psikoz), Kendini ermiş hissetmek (LSD, ibogain vb. veya psikoz) Gecmişe gitmek, gecmişteki olguları veya olayları hatırlamak (LSD, ibogain, THC, bu etki pek psikozda görülmez).” (Sayın, 2007: 95)

En bilindik halüsinojenlerin başında LSD gelirmektedir.(Sayın, 2007: 69) LSD ilk defa 1938'de sentetik olarak elde edilmiş, sonra çavdar mahmuzu taneciklerinden doğal olarak bulunmuştur.(Özkaya, 2013: 176) 1960'lı yıllarda kullanımı serbest bırakılmıştır.(Sayın, 2007: 69) Bu ilaç insanlarda anormal, beklenmedik davranışlar yaratılarak onları gülünç, kötü duruma düşürmek için kullanılabilir. Örneğin çayına 200 mikrogram LSD damlatılan bir kişi, bu maddeyi bilmiyorsa verdiği bir konferans esnasında, kahkahalarla gülmeye başlayabilir ya da sıvı THC de buna benzer, uyumsuz sayılabilecek davranışlara yol açabilir.(Sayın, 2007: 154) "İçkisine LSD veya uyuşturucu katılan kişilerin kolay intihar ettikleri ve kolay insan öldürdükleri bilinen bir gerçektir.”(Şimşek, 2005: 103) “LSD’nin sinir sistemince emilmesi hızlıdır ve kişi sırayla üç değişik etki duyar: 1.Kalp atışının hızlanması, atardamar basıncının yükselmesi, sindirim bozuklukları. 2.Algılama etkileri: Görsel ve işitsel belirtiler. 3.Ruhsal etkiler: Zaman kavramının bozulması, düşünce akışında bozukluklar, uyanıkken düş görme hali, kişilik kaybı duygusu, şiddetli değişmeler, kendilerine ya da başkalarına saldırganlık hali." Uyuşturucunun etkisindeyken paranoya belirtileri gösterenler de mevcuttur.(Özkaya, 2013: 175-176)

"Amfetamin gibi kimi kimyasallar (10-30 mg) alındığında (...) problem çözme ve öğrenme yeteneği hızlanır. Doz artınca $(50-70 \mathrm{mg})$ biraz paronaya başlar, kişinin alt yapısında psikoz varsa o 
tetiklenir. 100mg civarında ise bu uyarıcı bir halüsinojene dönüşür, halüsinasyonlar görülmeye başlanır."(Sayın, 2007: 69)

"Kimyasal savaş için sentezlenmiş olan MDMA isimli uyarıcı, insana barış ve uyum hissi verdiğinden istihbarat örgütleri tarafindan düşman askerlerinin yiyeceklerine katılmak suretiyle kullanılmıştır. Bu ilaç daha sonra depresyon tedavisinde etkili olmuştur.”(Sayın, 2007: 69)

'EA 1729'un potansiyel olarak tehlikeli bir uyuşturucu olduğu belirlenmiştir. Ayrıca kronik bir şekilde psikoz, ruhsal bozukluk oluşturma olasılığı özellikle deneğin şizofreniye eğilimli olması durumunda mevcuttur.”(Özkaya, 2013: 177-178)

"Peyote kaktüsünden elde edilen ve yine Kızılderililerin kullandığ mescalin halüsinojen bir maddedir. Mescaline, şahsiyet parçalanmasına sebep olur. En ufak şeylerin bile şahıs tarafından önemsenmesine yol açar.”(Brown, 2012: 192) “Cinsel davranışlarda değişiklik ve aberran bir yap1 oluşturmak, bu amaçla yüksek doz metamfetamin (80-100mg) insanlara gizlice verilerek afrodizyak etkileri incelenmiştir. Metamfetamin beyinde dopamine ve norepinefrini arttırarak limbik sistemde korkunç bir cinsel firtına yaratabilir. Aberran davranışlara eğilimli kişilerde bu davranışları ortaya çıkarır.”(Sayın, 2007: 155)

Çok kuvvetli bir halüsinojen olan BZ askerlerin daha saldırgan olmasını sağlar. (Sayın, 2007: 72) "BZ kod adlı madde 40 saat ile 4 gün arasında etkili, insanda delirium yaratan bir drogtur. BZ kulanan kişi, çevresinden tamamen izole olur, bir zombi gibi dolaşıp söyleneni yapar. Aşırı saldırganlık, paranoya, süreğen psikoz bu ilacın etkileri arasındadır."(Sayın, 2007: 146) "Skopolamin gibi bazı halüsinojenlerin de benzer etkileri vardır."(Sayın, 2007: 200)

"İbogain bir halüsinojen olup insan beyninde yaklaşık 2 gün süren psikedelik bir yolculuk yaşatan çok güçlü bir halüsinojendir ve eroin, kokain bağımlılı̆̆ında kullanılmaktadır. İbogain kişide çok farklı bilinç halleri yarattığı, geçmişe ait tüm anıları bir film şeridi gibi hatırlattığı, bilinçli rüya görme hali sağladığı için psikiyatırların, nörobilimcilerin ve kaçınılmaz olarak da istihbarat örgütlerinin ilgisini, aynı LSD gibi çekmiş bir ilaçtır.’(Sayın, 2007: 149)

Sodyum pentothal iğnesi: $\mathrm{Bu}$ ilacın tesirinde kalanlar, sorulan sorulara yalan cevaplar verememektedirler. Batı'daki polislerin bu ilacı kullanmalarına rağmen mahkemelerde delil olarak kullanılmamaktadır. Ancak kanıtların yeri ilacın etkisiyle söylenirse mahkemede delil sayılmaktadır.(Özkaya, 2013: 63)

"Normal insanlara yüksek doz antipsikotik ilacın verilmesi, aşırı sersemlik, huzursuzluk yaratabilir veya bazı NMDA reseptör antagonisleri insanlarda deliriumlar oluşturabilir ve tıp bu tarz maddeleri istihbarat örgütlerinin emrine 'hipokrat yeminini çiğneyerek' sunmaktadır.”(Sayın, 2007: 149)

"Yüksek doz atropine unutkanlık yapabildiği gibi, uzun süreli hafıza kaybı yapan daha güçlü bazı maddeler de mevcuttur, bu ilaçların "sıcak ve soğuk savaşlarda" kullanıldığına dair pek çok delil vardır. Örneğin ibotonik asit veya kainik asit, beynin hafıza ve üç boyutlu uzay algısından sorumlu hipokampus denen bölgesinde veya limbik sistemde geri dönüşsüz nöron ölümüne, aşırı unutkanlığa, psikoza ve sara nöbetlerine neden olabilir. Bu gibi kimyasal maddeler 'geri dönüşümsüz etkilerine 
ragmen' bazı istihbarat örgütlerinin cellat psikiyatrları tarafından insanlar üzerinde denenmektedir.”(Sayın, 2007: 149-150)

“Son yıllarda özellikle öne çıkan ilaç Haloperidol'dür. Bu ilaç tipik bir antipsikotiktir ve butyrophenone sınıfından kabul edilir. Farmakolojik etkileri fenotiyazinlere benzer. Haloperidol 1960'dan sonra şizofreni tedavisinde kullanılmaktadır. Ancak daha çok siyasi amaçla kullanılan sabıkalı bir üründür."(Çebi, 2012: 80-81)

\section{Psikolojik Travma}

İstihbarat örgütleri işkence yöntemlerini kullanmak ve bunları zihin kontrol projelerinde uygulamaya koymak konusunda sakınmamaktadırlar. Çünkü bazı zihin kontrolü projelerindeki psikolojik travma metotları gerçekte farklı işkence tekniklerinden ibarettir. İşkence gören insanlarda geri dönüşümsüz psikolojik, fizyolojik ve nöroanatomik etkiler meydana gelir. (...) Örneğin travma sonras1 stres bozukluğu, hem savaşan askerlerde hem de işkenceye maruz kalan insanlarda görülmektedir. (...) Esasen işkence, savaş durumundan çok daha ağır strese neden olmaktadır. "Stres insanlarda HPA ekseni denen bölgelerin aktivasyonu aracılığıyla aşırı CRF, ACTH ve kortizol salınmasına" yol açmaktadır. "Bu etki ise beyinde pek çok geri dönüşsüz nöron ölümüne, apoptozise neden olur. Bellek, üç boyutlu alg1, düşünebilme yeteneği körelir.” Ayrıca işkence gören insanların kronik depresyon, hafıza kaybı, paranoya, psikoz vb. gibi tüm psikiyatrik bozukluklara girme olasıllı̆ı artar. "CRF zaten aşırı salgılandığında depresyon yaratan bir hormondur. İşkencenin tipine göre geri dönüşsüz kardiyovasküler, üriner sistemle ilgili biyokimyasal ve nörolojik bozukluklar gelişir."(Sayın, 2007: 197) Alış1madık, uzun süreli çevresel stres veya yaşam durumları, kişiliğin normal fonksiyonlarını aksatabilir. Bu tür güçlüklere maruz kalan kişiler değişik bir kişilik ya da sahte kimlik benimseyerek yeni durumlara uyum geliştirebilirler.(Keith, 2006: 147)

1932 yılında, "CIA'in öncüsü Amerikan OSS istihbarat ağının kurucularından Alman psikolog Kurt Lewin", bireyleri ve toplulukları yeniden programlamak amacıyla travma tekniğinin kullanılmasını ilk savunan kişilerdendir. Lewin'in bu kuramı, yani özneyi sonraki yeniden programlamaya hazırlamak maksadıyla işkence ve travma yoluyla yapısını bozmak, "20.yüzyılın dünya zihin kontrolü ve kültürel programlaması yöntem bilimidir. (...) Korku, öfke ya da heyecan gibi duyguların, kasten ya da kasti olmayan biçimde uyarılmasıyla beyin işlevleri yeterince zarar gördüğünde, kişilere çeşitli inançlar dayatılabilir. Bu türden olayların neden olduğu sonuçlardan en yaygın olanları, geçici yargı bozukluğu ve yüksek derecede etkiye açık olma halidir. Bunun çeşitli grup tezahürleri bazen 'sürü dürtüsü’ başlığ altında tasnif edilir; endişenin arttığı ve dolayısıyla birey ve kitlenin etkiye açık hale geldiği savaş zamanlarında, ciddi salgınlarda ve benzeri tehlike dönemlerinde en görkemli halleriyle görülür.”(Keith, 2006: 40-41)

\section{Tecrit ve İşkence}

Tecrit ile beyin yıkama yöntemi arasında oldukça sıkı bir bağlantı bulunmaktadır. Gerçekte tecrit, beyin yıkama metodunu baz alan faaliyetten başka bir şey değildir. Tecrit, işkencenin farklı yöntemlerle uygulanması şeklidir. Tıplı işkencelerde olduğu gibi tecridin de esas amacı insanın kişiliğini yok etmektir. Tecrit ile duyumsal uyaranların sınırlandırılması bireyde duygusal bir yıkıma neden olur. Tecridin diğer bir maksadı da şahsın sosyal çevreyle olan bağlantılarının tamamen yok edilerek bireyin mutlak yalnızlaştırılmasıdır. Tecritteki birey kimseyle konuşamaz, duygu ve düşüncelerini sesli olarak kimseyle paylaşamaz, sesleri olduğu gibi duyması ve algılamasına izin verilmez. Bu şekilde toplumsal 
tüm ilişkileri koparılmış kişi, yalnızlaştırılarak kendisiyle hesaplaşmaya zorlanmakta böylece iradesi zayıflatılan birey teslim alınmaya çalışılmaktadır. Tecritte kişinin davranışları kontrol edilerek politik kişiliğinin yok edilmesi hedeflenmektedir.(Koşan, 2000: 17,23)

“Tek kişilik ya da küçük gruplar olarak tecritte kalan kişilerde, birçok durumda patalojik rahatsızlıkların saptandığını ve tecritte kalan kişilerin Dr. Sluga'nın 'Uzun Zaman Tutsakları' adlı araştırmasında da izah ettiği gibi oldukça ciddi Seperations-Syndrom'dan acı çektikleri tespit edilmiştir. $\mathrm{Bu}$ olayların birkaçında vegetative sinir sistemi rahatsızlıklarında olduğu gibi şiddetli entellektüel ve duygusal rahatsızlıklar ortaya çıkmaktadır. Oluşan rahatsızlıklar deneysel durumlarda sensorik deprivasyon aracılığıyla yaratılan etkileri hatırlatmaktadır."(Koşan, 2000: 136)

Uzun süreli Duyusal Yoksunluk (Sensorik Deprivasyon) sonucunda halüsinasyonların ve birtakım ilaçlarla erişilen durumların meydana geldiği bildirilmiştir.(Sayın, 2007: 161) Ses geçirmez bir odaya konarak fiziki çevresiyle bağlantısı kesilen bir insan, belli müddet sonra canlı ya da cansız hayaller görmeye başlar.(Brown, 2007: 205) Yapılan deneylerle "mutlak bir sessizliğin, insanı olmayan şeyleri görür ve işitir hale getirdiği”" ortaya koyulmuştur.(Brown, 2007: 194)

\section{Zihin Bulandıran Gazlar, Mikroçipler, Elektromanyetik Dalgalar, Psikotronik Silahlar...}

Dünyanın en geri kalmış ülkelerinde dahi zihin kontrolü deneyleri ve uygulamaları yapılmaktadır. Sinema veya TV yoluyla alt beyni programlamak, zihin bulandıran gazlar, beyne ya da vücuda yerleştirilen mikroçipler, elektromanyetik dalgalar, psikotronik silahlar (sessiz silahlar) kullanmak uzaktan zihin kontrol yöntemlerinden bazılarıdır. (Şimşek, 2005: 49,51)

Önceki başlıklarda bahsettiğimiz sinema veya TV'nin dışında beyni etkilemek için gaz da kullanılmaktadır. Örneğin; bir kediye ilaçlı gaz püskürtülüp büyük bir kavanoza konmuştur. Sonrasında yanına bir fare bırakılmıştır. Kedi fareyi görünce çok korkmuş, panik halindeki hayvan camı tırmalayıp kaçmaya çalışmışır. Bu deney, beyindeki 'korku' bölgesini, amigdala bezesini gaz yoluyla etkilemek suretiyle gerçekleştirilen bir deneydir. Kedi-fare örneğinde olduğu gibi insanları etkilemeye yönelik olarak tasarlanmış bir gaz, fark ettirmeden şehirlere, ordulara, yöneticilere püskürtülürse panik, teslimiyet, her şeye boş verme gibi türlü davranışlara sebep olacaktır. Bunlara 'psiko-motor' ilaçlar denmektedir.(Özkaya, 2013: 65)

İlk küçük adımları 1786 tarihine kadar götürülebilecek olan ve günümüze kadar yapılan çalışmalar neticesinde insan davranışlarının; tehlikesiz doku ısınması oluşturulması, işitsel korteksin uyarılması, beyin ritminin modifike edilmesi ve mikrodalgaların çok çeşitli biyolojik uygulamalarıyla değiştirilebileceği ve istenilen şekilde yönlendirilebileceği tespit edilmiştir.(Victorian, 2007: 174) Deneysel psikolog Dr. Delgado, boğaya, televizyon kumandasına benzeyen bir araç ve daha önce derisinin altına yerleştirilmiş çipler vasıtasıyla, beyninin öfke ve huzur bölgelerine elektirik akımı vererek istenilen davranış1 yaptırmıştır.(Şimşek, 2005: 28)

Kişileri uzaktan hipnoz etmek üzerine de çeşitli çalışmalar yapılmıştır. Örneğin Radyo Hipnotik Beyinlerarası Kontrol Projesi (RHIC), CIA'in resmen hiçbir zaman kabul etmediği gizli projelerden biridir. İnsanda hipnotizma etkisi oluşturmak için yapılması gereken tek şey, hedef olarak şeçilmiş kişinin belirlenen bir kasına stimociever(mikro küçültülmüş elektronik cihaz)'ın enjekte edilmesidir. Bu işlem için yaygınlıkla kullanılan yerler burun ve kulak delikleridir. Bu yöntemin yanında yani RHIC'nin yeni bir şekli olarak Hafızanın Elektirikle Eritilmesi (EDOM), ortaya çıkmıştır. EDOM hedef kişide 
'kayıp zaman' duygusu meydana getirmek ve hafizanın kısmi olarak silinmesi maksadıyla uygulanmaktadır. Aynı etkiyi, aşırı dozda 'acetochaline' ile beyin hücrelerinden bazılarının basit bir şekilde engellenmesiyle veya elektronik 'kitleme' yoluyla oluşturmak mümkündür. Ayrıca bu kimyasal tekniğin dışında 'kayıp zaman' etkisi yaratmak için elektromanyetizma ve mikrodalgalar da kullanılabilmektedir. Ve yine EDOM, uzaktan hipnotizma etkisi meydana getirmek maksadiyla kullanılan araçlardan biridir. Kaynağı CIA olan bir belgeye göre, insanlar bu şekilde sistemli telkinlerle intihar emirlerine bile itaat edebilirler.(Victorian, 2007: 168-171)

Sinir cerrahı W. Penfield elektrik akımını, beyin ameliyatları sırasında beyin dışındaki bölgeyi uyarmak amacıyla kullanmıştır. Bu yöntemin uygulandığı epilepsi hastaları, geçmiş yaşantılarının tümünü yeniden hissetmişlerdir. Allan H. Frey, 1961'de baş bölgesine düşük güç yoğunluklu UHF elektromanyetik enerji gönderilmesinin, radyo dalgalarına benzeyen ışınlar yayarak kişide ses algılaması meydana getirdiğini kanıtlarla ortaya koymuştur. Ordu için çok geniş uygulama sahası ve yeni bir haberleşme şekli olan radyo dalgaları vasıtasıyla beyinle doğrudan haberleşme keşfedilmiştir. "Nabız sayısına ayarlı sinyal gönderici cihazların, gönderilen sinyalle istenen bilgiyi nakletmeleri artık hayal olmayacaktır. Hatta beyne herhangi bir kelimeyi göndermek mümkün olabilecektir. (...) Uzaktan hipnozla programlanabilecek ve hipnoz esnasında bilinçlerini aşan emirlerle yönlendirilecek istihbarat elemanları, verilen görevleri yerine getirebileceklerdir. Hedefin itaatettiği herhangi bir hipnotik komut, hedefin görünürde kendi beyni içinde doğan kendi fikri olarak kabul edilebilir.” (Victorian, 2007: 174179)

Ses konusunda en büyük sorun sesin havada çok fazla dağılması ve tek bir noktaya odaklanmamasıdır. Ancak Amerikalı ses mühendisi Joe Pompei, sesi tek bir noktaya göndermeyi başarmıştır. Pompei bu icadına "Audio Spotlight" adını vermiştir. Bu tekniğin temel prensibi ultrasonik dalgaların lazer 1şınına benzer bir şekilde dağılmadan tek bir noktaya odaklanabilmesidir. Bu cihaz yardımıyla kalabalık içerisindeki bir kişiye sadece onun duyabileceği şekilde ses göndermek mümkün olmaktadır. Başka bir yöntem ise iç kulakta bulunan bezelye büyüklüğündeki sakkula organının ultrasonik ses dalgaları vasıtasıyla uyarılmasıdır.(Şimşek, 2005: 45-46) “Özellikle iç kulağa yerleştirilen elektronik devre, mikrodalga silah endüstrisi açısından insan beyninin yüzde yüz kontrolünü mümkün kılmaktadır."(Özkaya, 2013: 94) Deride ya da damarlarda ve kemiklerde oluşturulan saf titreşimler de kişi tarafından ses olarak algılanabilmektedir. Infrasound denilen duyum eşiğinin altındaki sesler vasıtasıyla uzaktan kişinin derisi üzerinde saf titreşimler meydana getirmek mümkün olabilmektedir. "Eğer uzaktan gönderilen sesler insan kulağının duyum eşiklerine çok yakın frekanslarda ise kişi konuşulanları şuurlu bir şekilde duymayabilir, fakat beyin tarafından verilen mesaj alınır böylelikle gizli telkin gerçekleşmiş olur.”(Yörükoğlu, 2012: 155) Ümit Sayın, ses dalgalarının ve duyulmayan eşik altı seslerin insanlarda strese, anksiyeteye veya psikolojik rahatsızlıklara yol açabileceğini ifade etmiştir.(Sayın, 2007: 220)

Kişileri izlemek ve onların beyinlerindeki işitsel-görsel bilgileri denetlemek amacıyla kullanılan çift yönlü geniş bir Uzaktan Nöral Denetim Sistemi mevcuttur. Bu işlemlerin hepsi, kişiyle fiziksel bir temas olmaksızın yapılır. Uzaktan Nöral Denetim tekniği, gözetim ve yurt içi istihbarata yönelik esas yöntemdir. Bu yolla konuşma, üç boyutlu ses ve şuuraltı ses, kulaklar devre dışı bırakılarak kişinin beyninin işitme korteksine gönderilebilir. Bu metodun, paranoid şizofreninin karakteristiği olan işitsel halüsinasyonların taklit edilmesiyle kurbanlara fark ettirmeden onların gücünü ve azmini kırmak için kullanılabileceği de bildirilmiştir. Uzaktan Nöral Denetim Sistemi gözleri ve optik sinirleri atlayıp devre dışı bırakarak doğrudan doğruya görsel kortekse görüntü gönderebilir. Ajanlar beyni programlamak 
maksadıyla gözetim altındaki kişi REM uykusundayken, onun beynine gizlice görüntü yollamak için bu teknolojiyi kullanabilmektedirler.(Şimşek, 2005: 115-116; Y1lmaz, 2006: 632; Y1lmaz, 2014: 186)

Gaibten sesler duyduklarını ifade eden zihin kontrolü programlarının tüm kurbanları, psikiyatrik destek almaları önerisiyle ile oyalanmıştır. Fakat elde edilen kanıtlar zihinde sesler üretebilen teknolojinin mevcut olduğunu göstermektedir. Örneğin ABD Patent Dairesi, Psiko-Akustik Projektör'ün ayrıntılarını şöyle tarif etmektedir: "Bu silahın amacı, hedefi hareketsiz kılarak, yoğun işitsel ve psikolojik rahatsızlıklar oluşturmaktır." Yine bu konudaki çeşitli araştırmaların verileri şöyledir: "İnsan zihninin yapısını değiştirme sistemi, tercihen ses gibi farklı frekans ve dalga şekilleri olan çeşitli uyarıcıların eş zamanlı olarak kullanılmasını içeriyor.”(Victorian, 2007: 212-214)

İnsan beyninde görüntü algısını uzaktan bir etkiyle oluşturulması, özel ilaçların tesiriyle veya beynin elektriksel uyarımı ile mümkün olabilmektedir. Beynin frontotemporal bölgesinin elektriksel uyarımı denekte halüsinasyonlara neden olmaktadır. Bazı hastalarda ise temporal lobun uyarımı müzik duyuyormuş hissi yaratmaktadır. (Şimşek, 2005: 47-48)

Mikrodalga aracılığıyla kişide uzaktan görüntü hissi yaratmak mümkündür. "Çok düşük frekansta, iyonlamanın olmadığı bir radyoaktivite ile baş ağrısı, çınlama, sinirlilik, depresyon, hafıza kaybı hatta panik duygusu oluşturulabilir."(Şimşek, 2005: 104) Pandora Harekatı'nda da kullanılmış olan mikrodalga radyasyonun insan üzerindeki belirtileri; "aşırı yorgunluk, devamlı veya ara sıra olan baş ağrıları, sinir, uykusuzluk, hafiza güçlükleri, fiziksel stresin ardından kalp bölgesindeki görülen ağrılar, nefes darlığı, istahsızlık, kalbin büyümesi ve kalple ilgili diğer sorunlardır.” ABD devlet bakanlığı raporunda uzaktan hedef kişiye yönlendirilen bir radarın, hedefin kalp krizi geçirmesini sağlayacağını bildirilmektedir.(Victorian, 2007: 180) V.P. Kaznacheyev adındaki bir bilim adamı, 1974 yılında uzak bir mesafeden ultraviyole ışınlarının nakledilmesinin insanı öldürebileceğini, Çek mühendis Robert Pavlita da 'psikotronik' cihazlar vasitasıla uzak mesafeden böceklerin öldürülebileceğini kanıtlamıştır. "CIA'in Pavlita'nın çalışmalarıyla ilgili raporuna göre, bu bilim adamı insanda güçlü psikolojik rahatsızlıklara, şiddetli ve kontrol edilemez duygulara felç veya ölüme neden olacak kapasiteye sahip olan, biri 320 km, diğeri daha uzun mesafeden etkili olan iki 'psikotronik' silah geliştirmiştir.”(Özkaya, 2013: 52)

Düzen tarafindan istenmeyen, tehlikeli olarak nitelendirilen insan ya da insan grupları olabileceği gibi herhangi bir birey de istihbarat ajanlarının uzaktan beyin kontrolü deneylerinde kobay olarak kullanılabilir. Bu hedefler içinde etnik azınlıklar, yabancılar, psikolojik olarak sağlıksız kişiler, cinsel sapmaları olanlar, uyuşturucu bağımlıları, mahkumlar, suçlular ve ölümcül hastalar da vardır. Suikast girişimlerinde bu sessiz silahlar, mevcut düzenin statükosunu bozmaya, değiştirmeye çalışan ya da çalışabilecek herhangi bir kişiye veya kişilere karşı kullanılmaktadır. Aynı zamanda hassas alanlardaki bilgilere erişen ve bunları açıklayan bireylere yönelik bir tehdit olarak da karşımıza çıkmaktadır. Asker ve polis kökenli istihbarat personeli ile karanlık devlet görevlerinde çalışıp bu yapıların gerçek niyetini anlayarak hareketi sorgulamaya başlayan kişiler de suikast listesinde yer alır. İstihbarat ajanları sessiz silahların varlığını artık gizlememelerine karşın bu silahların sürekli ve giderek artan bir şekilde toplum üzerinde, uzaktan beyin kontrolü deneyi, davranış manipülasyonu ve suikast amacıyla kullanıldığını inkar etmektedirler. İstihbarat ajanları, bu gerçeği açıklamak isteyen kişilerin saygınlığını yok etmek için de çaba sarf etmektedir.”(Özkaya, 2013: 113-114) 


\section{“Kuantum Şifresi”" ve Casusluk}

"Kuantum Şifresi” romanının konusu güç mücadelesi etrafindaki casusluk faaliyetleridir. Bu bakımdan öncelikle casusluk mesleği ve casus psikolojisi üzerinde duracağız. Devletler arasındaki rekabet ve savaş arttıkça, birbirine meydan okuyan güçler, harpler çoğaldıkça casuslarda ve casusluk faaliyetlerinde de artış yaşanacaktır. Dünyanın dört bir yanına dağılmış kadroları, dev bütçeleri ve teknik altyapılarıyla istihbarat kuruluşları, devletlere yön veren 'gizli iktidar' odaklarından en önemlilerini oluşturmaktadır. (Bahar, 2009: 22-23) Peki bu gizli iktidarın gücünün teminatı niteliğindeki "casus" kimdir? İlhan Bahar, 'İstihbarat Örgütlerinde Beyin Yıkama' adlı kitabında casusluk mesleği hakkında şu bilgileri vermektedir:

Casus, duygularının olmaması gerektiğine, duygularıyla yaşamamaya şartlanmış insandır. Gerektiğinde hiçbir suçu olmayan ya da hayatında hiç görmediği, tanımadığı, kendisine herhangi bir zararı dokunmamış insanlara bile kötülük yapmak hatta onları öldürmek zorunda kalabilir. "Normal bir insanın bunu yapması mümkün değildir. Bu anlamda casusluk 'normal insanların', duygularıyla hareket eden, ahlaki değerlerin etkisinde kalan ve içinde bir parça da olsa insani hassasiyetler taşıyanların kolaylıkla yapabileceği bir iş değildir." Bütün bunlardan büyük bir haz alan, maceraperest veya gizli bir gücün arkasında esrarengiz işler çevirmekten hoşlananların egolarını tatmin edecekleri bir faaliyet alanıdır. Öncelikle saha casusu ile masa başı casus ayrımı yapılmalıdır. İşin bütün ağırlığı saha casuslarının üzerindedir. Bütün riskler, her türlü zorluklar onların omuzlarına yüklenmiştir. Dolayısıyla en çok gerilim yaşayan onlar olduğu gibi işin faturasını en fazla ödeyecek olan da onlardır. Masabaşı casusları ise daha çok analiz, yönlendirme, değerlendirme, veri toplama ve saha casuslarından gelen ham bilgileri işleme ajanı gibi görev yaptıklarından saha casuslarının yaşadıkları risk ve gerilimleri fazla yaşamazlar. "Sahada çalışanlar ise gündelik stresten tutun, paranoya ve kişilik bozukluklarına kadar geniş bir yelpazede etki altında kalırlar. Bunlara kendi kişisel hayal kırıklıklarını, beklentilerinin karşılanmaması gibi diğer sorunları da eklerseniz ortaya daha kızıştırıcı etmenler de çıkacaktır.” Başka bir psikolojik bozukluk ise casusun megalomani içine girmesidir. Arkasına aldığı örgütün desteği ve kimsenin bilmediği sırlara sahip olma duygusu, o kişiyi farklı bir psikolojiye sürükleyebilir. Bu psikoloji özellikle karar verici konumda olanlarda görülebilir. Burada sözü edilen güç yasalarla sınırlandırılmamış veya yasaları aşan bir güçtür. Onlar saplantı haline getirdikleri bir yazarla, bir fikirle ya da o an için tehlikeli gördükleri herhangi bir şahısla özel olarak ilgilenebilirler. Eylemleri artık rasyonel etikten çıkıp sadece bir güç kanıtlama ihtiyacına dönüşebilir. Bununla beraber casusluk faaliyeti içinde olan hemen hemen herkeste ortak bazı şikayet ve problemlere rastlanabilir.(Bahar, 2007: 24-27)

Her meslekte olduğu gibi bu mesleğin de bazı ölçütleri vardır. Bu bakımdan her casusluk oluşumu yasal veya yasa dışı yöntemlerle kendine uygun kadroları arar ve bulur. Bu alana devletin çeşitli birimleri içinde ordu, polis, dışişleri görevlileri vb. gibi içeriği uygun bölümlerden kadrolar aktarılabilir. Ancak casus seçmenin her zaman 'gönüllü' kanallardan yapıldığı sanılmamalıdır. "Casusluk örgütleri insanları tuzağa düşürmek, şantaj yoluyla kendileri adına çalışmalarını sağlamak, ağızlarından istedikleri bilgiyi almak ve benzeri nedenlerle insanların zaaflarını kullanırlar. Bunun için sürekli izledikleri veya bir şekilde zaaflarını öğrendikleri kişilerin bu yönlerinin üzerine giderler. "Aile zaaflarından, cinsellikten, paranın gücünden, toplumda saygınlık isteğinden, zor şartlardaki çaresizlik duygusundan, kendini kanitlama dürtüsünden, toplumsal ve kültürel şartlanmalardan, ulusal duygulardan, idealist düşüncelerden ve gizemli konulara olan meraktan da yararlanılır."Eğer karşılarındaki kişinin belirgin bir zaafı yoksa bu defa da o kişiyi, ailesini öne sürerek kendilerine 
çalışmaya zorlarlar. Bu gibi durumlar devletlerin yasalarına tabi olarak kurulan örgütlerin, nasıl birer uç organizasyona dönüşebileceklerine işaret eder.(Bahar, 2009: 8,29,39,95)

"Kuantum Şifresi" romanında casusluk mesleği, bu mesleğin faaliyet alanları, ajanların yaşadıkları güçlükler ve onların psikolojilerine başarılı bir şekilde yer verilmiştir. İlhan Bahar'ın kitabı ışığında, casusluk faaliyetleri hakkında, yukarıda kısaca vermiş olduğumuz bilgilerin, romanın anlaşılmasına katkı sağlayacağı ümidindeyiz.

\section{Romanin Özeti}

ABD Ulusal Güvenlik Ajansı (NSA)'da çalışan Fitz Patrick Garner, direktörü olduğu "Kuantum Kripto Projesi" ${ }^{1}$ nde görevli bir ekiple birlikte çalışmaktadır. Arsen Bora ${ }^{2}$ bu ekip içindeki "yeni nesil beyinler"dendir.(s.15) Arsen'in yolunun NSA ile kesişmesini sağlayan olay 2000 yılında TÜBİTAK' Türk Silahlı Kuvvetleri (TSK) "için askerî iletişimin güvenliği ve ulusal şifreleme teknikleriyle ilgili bir projeye" başlamasıdır.(s. $28^{3}$ ) Birkaç ay sonra NATO'nun da benzer içerikli bir projeye imza atmasıyla birlikte bu iki proje birleştirilmiş, bu nedenle Arsen, NATO'nun yürüttüğü çalışmada görevlendirilmek üzere Amerika'ya yollanmıştır. Ancak proje ekibindeki elemanların can güvenliği tehlikededir. Çünkü bu bilimsel tasarı, ticaret ve sömürgecilik yoluyla hayatta kalmaya çalışan ve "ülkeler üstü bir oluşum"(s.41) olan Umbranautlar'ın çıkarlarıyla örtüşmemektedir.

\footnotetext{
${ }^{1}$ Projenin ev sahipliğini Amerika yapıyor olmasına karşın, onun esas sahibi NATO’dur. Altan Çimen, Kuantum Şifresi, Doğan Kitapçılık, İstanbul, 2004, s. 16.

2 Arsen Bora mühendislik üzerine eğitim alıyorken fizik lisans programına da kaydolarak "dauble major" yapmiştır.(s. 28)

${ }^{3}$ Sadece sayfa numarası belirtilen alıntılar "Kuantum Şifresi” romanından alınmış anlamına gelmektedir.
} 
Romanda Umbranautlar için çalışan GORI ${ }^{4}$ ve Pluto adlı iki kuruluştan bahsedilmiştir. GORI "çok uluslu şirketler için dünya üzerindeki firsatları bulmak ve pazarlamak"(s.36) amacıyla oluşturulmuş yasal bir yapılanmadır. "Müşterileri genellikle uluslararası şirketler ve değişik ülkelerin yönetimleri”dir.(s.42) GORI'nin başkanı olan Lou Walltrip ${ }^{5}$ CIA tarafından eğitilmiş bir saha ajanıdır. Walltrip başkan olmasına rağmen işle ilgili tüm sorumluluğu eski bir MI-6 ajanı olan yardımcısı Sarah Concord $^{6}$ üstlenmiştir. Walltrip'in asıl yönettiği yap1 GORI'nin 120 metre altına inşa edilmiş Pluto'dur.(s.39) "Teknolojik casusluk alanında dünyanın bir numara"sı haline gelen Pluto bir yeralt1 organizasyonu olarak faaliyet göstermektedir. En önemli prensibi gizliliktir. Tek amacı Umbranautların çıkarlarını korumak olan bu oluşumdan "gizli servisler de dahil olmak üzere hiçbir örgüt" haberdar değildir.(s.43,55)

"NSA dünyayı dinlerken, Vulkan sistemi de NSA'yı dinlemektedir ve bundan kimsenin haberi yoktur."(s.43) Çünkü Umbranautlar için çalışan üçşirket "NSA'nın Echelon II projesi için açılan ihaleye girmiş" ve yeryüzündeki en güçlü "rakiplerine, kendi kullandıkları sistemi pazarlamışlardır."(s.43)

$\mathrm{Bu}$ gizli kuruluş için çalışan şirketler, "NSA'ya sattıkları sisteme saha ajanı adını verdikleri yapay zekâ yazılımlar yerleştirmişlerdir. Saha ajanlarl, NSA'ya pazarlanan sistemin en sofistike unsurlarlydır; görevleri, bulunduklart sistemden geçen veya sistemin içinde bulunan bilgileri incelemek, değerlendirmek ve gerekmesi halinde istenilen yere yollamaktır. Saha ajanları sistem içindeki varlıklarını neredeyse görünmez kıldıkları için, sistemin güvenlik ve bakım yazılımları tarafindan algılanmaları imkânsızdır. Bu şekilde, NSA'yla güvenli bağlantı kuran bütün birimlerdeki bilgilere erişmeleri mümkün olabilmiştir. ”'(s.43)

\footnotetext{
${ }^{4}$ [Global Opportunities Research Institute (Global Olanaklar Araştırma Enstitüsü)] “GORI kuruluşlara gerek bilgi, gerekse operasyonel destek sağlayan legal bir kuruluştur. (...) Kuruluşlar bir yere yatırım yapmadan önce GORI'ye gelip, yatırım yapacakları coğrafya hakkında bilgi talep ederlerdi. GORI de, yatırım yapulacak coğrafyanın, iklimi, etnik, politik, coğrafi, askerî, vb özellikleri hakkında kuruluşu bilgilendirirdi. Bu verdikleri hizmet türlerinden biriydi. İkinci tür hizmetler ise, iş bitirici yardımları içeriyordu. Sorun yaşayan kuruluşlar onlara başvurup, çıkarlarının korunmasın istediklerinde, sorun çıkaran yönetimlere ve gruplara karşı caydırıcı yöntemler uygulanmasına yardım ediyorlardı. Bütün bu hizmetlere ek olarak, hukuki yapıları gereği, faaliyet göstermekten çekindikleri alanlarda hükûmetlere gerek lojistik, gerekse operasyonel destek sağlyorlardl. GORI'nin verebileceği hizmetlerin iki şartı vardı. Birincisi verilen hizmet Umbranautları deşifre etmeyecek ve ikincisi de Umbranautların çıkarlarına aykirı olmayacaktı. Bu iki şart da Pluto dışındaki bir oluşum tarafindan hassasiyetle incelenirdi." (s.42)

${ }^{5}$ Lou Walltrip MIT'de fizik alanında eğitim almıştır. Aynı zamanda güzel sanatlara da ilgi duymaktadır. Mesleği askerlik olmamasına rağmen “CIA 'in dördüncü direktörü olan General Walter Bedell Smith'in Truman'a verdiği brifing sonucunda, askerler dışında resmi görevlilere ve seçilmiş kişilere istihbarat eğitimi verilmesi kararı” ile “Şirket'e ilk girenlerden birisi olmuştur.”(s. 39) 1957 yılında Rusların uzay teknolojileri alanındaki gelişimini yakından izlemek maksadıyla Avrupa'ya yollanmıs, Berlin Teknik Üniversitesi’nde fizik doktoru olarak görevlendirilmiştir.(s.40)

6 “Concord eski bir MI-6 ajanı" dır.(s.51) Asıl soyadı Veneer'dir. MI-6 hakkında bilgi almak için tutulduğu sorgu hücrelerinden kurtulduktan sonra soyadını değiştirmiştir.(s.101)
} 
Vulkan sistemi, elindeki bilgilerin \%65'ini NSA'ya satılan sistemin içine yerleştirilmiş saha ajanlarından sağlamaktadır. Bu nedenle Umbranautlar için çalışan kuruluşlar "Kuantum Kripto Projesi"nin başarıya ulaşmasını istememektedir. Eğer proje planlandığ 1 gibi yürürse "birilerinin hatta sızdığı" anlaşılacağı gibi fiber optik hat da güvence altına alınacak, böylece Vulkan sistemi önemli bir bilgi kaynağından mahrum kalacaktır. Bunu önlemek için iki seçenekleri vardır: " $y a$ NSA'nın kaynaklarını gizlice kullanmaktan vazgeçeceklerdir, ya da NATO'nun projeden vazgeçmesini sağlayacaklardır. NSA'dan bilgi almaktan vazgeçemeyeceklerine göre, seçenek oluşturacak bir yöntem keş̧fedene kadar, projenin başarısız olmasını sağlamaları" gerekmektedir.(s.44)

GORI'nin başkan yardımcısı Sarah Concord, “NSA'nın içinde bir operasyon başlatarak" proje ekibinden "Kuantum Kripto Projesi”nin direktörü Fitz Patrick Garner'ın ve "projenin birinci aşamasının tamamlanmasını" sağlayan Arsen Bora'nın öldürülmesi emrini vermiştir.(s.52-53) Lil Sutack, Garner'1 ortadan kaldırmak için onu takip etmiş, eve dinleme sistemi yerleştirmiş ve Meade Golf Kulübü'nde ona "nano enjeksiyon" "7 yapmıştır.(s.17) Kanına karışan zehir Garner'ın bilinçaltındaki en korkunç kabuslarını ortaya çıkarmış ve sanrılar görmesine neden olmuştur. Gerçekle hayal dünyası arasındaki sınırlarda dolaşmakta olan kahraman kendi korkularından oluşan bir hayal sarmalı içinde, yaşadıklarından hangisinin gerçek hangisinin hayal olduğunu ayırt edecek durumda değildir.(s.21-22) Yaşadığı kötü deneyimden dolayı kendini savunma ihtiyacı hissettiği için eline aldığı Wesson 380’lik tabancasıyla penceredeki gölgeye doğru ateş etmeye başlayan Garner, polislik yapan Çavuş Jason Mender'i kasığından yaraladıktan bir süre sonra öfkeli polisler tarafindan yaylım ateşine tutularak öldürülür.(s.22-25,56) Ancak Arsen Bora'yı ortadan kaldırmaya yönelik girişimler başarısızlıkla sonuçlanır.

“Akıl sinırlarını zorlayan” bu operasyon Pluto'nun gizliliğini tehlikeye sokmuştur. Bu durum karşısında oldukça sinirlenen başkan Lou Walltrip, Pluto' da yapılan toplantıda yardımcısının onayladığı bütün operasyonların askıya alınması, (s.52-53) $\mathrm{KFT}^{8}$ (Kişisel Tehdit Faktörü) ve GTF ${ }^{9}$ (Global Tehdit Faktörü) değerleri yüksek olan Arsen Bora'nın ise Kuantum Kripto Projesi'nden el çektirilmesi emirlerini verir.(s.63) Aynı zamanda Timoty Diaz'ın, akıllı ve yetenekli bir genç olan Arsen Bora'yı kendi saflarına çekme fikrine sıcak bakan Walltrip, onun kendi şirketlerinden birinde çalışmasını sağlamak üzere Dorothy Ruth ve Diaz'1 görevlendirmiştir.(s58-59,63)

$\mathrm{Bu}$ arada projenin tehdit katsayısını düşürmek için burada görev alan Marco Marconi'nin de saf dışı bırakılması emri verilmiş, listede ismi olmayan Laura Hayes da Marco ile birlikte olduğu için nano

\footnotetext{
7 “Mikroskobik boyutlarda yapılan enjeksiyon. ”(s.17)

8 “Kişisel Tehdit Faktörü, Pluto tarafindan kullanılan, bireyler ile ilgili bir değerlendirme sistemiydi. Pluto'nun ilgilendiği her kişi için, yaklaşık olarak 300 kişisel özelliği göz önüne alınarak hesaplanıyordu. KTF değeri, karar verme aşamasında nihai bir kriter olmamasına karşın, kişinin Pluto için ne kadar tehlike oluşturduğunu gösteriyordu. KTF değeri 0.300 düzeyine gelmeden, bireylere karşı aktif müdahale yapılmazdı. ”(s.60)

9 “'Global Tehdit Faktörü (GTF) ise bir kişinin veya kurumun, etkileşimde bulunduğu kişi veya kuruma göre oluşturduğu tehdidi gösteriyordu. (...) Bir kişinin GTF değeri iki şekilde düşürülürdü. Ya kişi saf dışı edilirdi ya da kişinin yaptığı işle ilişkisi kesilirdi. Pluto'da genellikle uygulanan yöntem, kişinin işten uzaklaştırılmasıydı. Zorunlu olmadıkça safdışı etme yoluna gidilmezdi. ’(s.60)
} 
enjeksiyona maruz kalmıştır. İki sevgili aynı arabanın içinde yapılan nano enjeksiyonun etkisiyle can verirler.(s. 63-79)

Pluto çalışanları, Los Alamos ${ }^{10}$ taki proje ekibinin başına kendilerinden olan Kevin Downing'i sokmuşlardır.(s.58) Arsen Bora'nın, Downing'in Kuantum Kripto Projesi'nin direktörü olmasından üç hafta sonra projeden istifa etmesini sağlarlar. Böylece Umbranautlar, NATO'nun “Kuantum Kripto Projesi”ni iptal ettirmeyi başarır.(s.87,103)

Walltrip emekli olunca Pluto'nun başına Sarah Concord geçer.(s.101) Concord'un Arsen Bora'ya yönelik düşünceleri değişmemiştir. Onun bir gün başlarına bela olacağını düşünmektedir. Çünkü saflarından olmayan başarılı insanlar, "kendileri için çalışmazlarsa başkaları için çalışırlardı"... Bunu daha önceki tecrübelerinden bilmekteydi.(s.104) Bu yüzden Pluto'nun yeni başkanı, 11 Eylül saldırılarından sonra İstanbul'a dönen Arsen Bora'yı ve eşi Melody Duncan'1 ortadan kaldırma konusunda kararlıdır. $\mathrm{Bu}$ iş için eski Stasi ${ }^{11}$ ajanı Markus Ludwing ${ }^{12}$ ve yanında dört kişiyi daha görevlendirir. Ludwing'in yanında seçilenler, Hollanda gümrüğünde $250 \mathrm{gr}$ uyuşturucuyla yakalanan bir mafya grubudur.(s.133,139) Bu grup içinde Metin Karakul ve Osman Selence eski birer teröristtirler. Bekir Turan ve Hamit Erduru ise mafyayla ilişkileri nedeniyle çevik kuvvetten atılmışlardır.(s.133) CIA'in bölge şef yardımcısı Julius McGinley gümrükteki mallarının kurtarılması karşılığında, bu adamları evli çifti öldürmeleri için ikna eder.(s.141) Melody ${ }^{13}$ öldürülür ancak Arsen Bora’yı öldürmeyi başaramazlar. Ludwing, Metin Karakul'u ortadan kaldırmak için nano enjeksiyon yapmış, çatışma sırasında Metin Karakul'un ortağı Osman Selence ve diğer iki adamı; Bekir Turan ve Hamit Erduru, Arsen Bora'nın Hammerli 208'inden çıan kurşunla öldürülmüştür.(s.186,187) Pluto, verilen görevi başaramayan Ludwing'i öldürmek için dört tetikçi yollamış, eski Stasi ajanı dördünü de saf dışı bırakmıştır. Ancak Ludwing, Arsen Bora için aktif hale getirdiği iğneyi yanlışlıkla kendi bacağına batırınca "yüzügün içindeki yüzlerce nano makine vücudunun içine girer". Bu arada Timur, arkadaş1 Arsen'i korumaya çalışırken Ludwing'in nano enjeksiyon iğnesine maruz kalmıştır.(s.258). Okul yıllarında nano enjeksiyonla ilgilenmiş olan Arsen, MR cihazının güçlü manyetik alanından yararlanarak Timur'un vücuduna sızmış olan nano makinelerin programlarını bozmayı başarır.(s.266) $\mathrm{Bu}$ arada Ludwing camdan atlayip intihar eder.

Arsen Bora ile arkadaşı Timur Sarp, Türkiye'de "ARTIM" adlı bir yazılım şirketi kurarlar.(s.103) İki arkadaş "GhostWall” isminde bir ateşduvarı geliştirir ve onu çeşitli şirketlere pazarlarlar. Bir gün "ARTIM”ın müşterilerinden biri olan ve "dünyanın neredeyse bütün havayolu

\footnotetext{
10 “Kuantum Kripto Projesi'nde, biri Fort Meade'de ve diğeri Los Alamos’ta olmak üzere iki ekip halinde çalışıyorlardı. Arsen'in içinde bulunduğu simülasyon ekibi, Fort Meade'de olası kuantum şifreleme çözümlerinin simülasyonlarını yaparken, Los Alamos’taki ekip fiber optik sistemler üzerinde kullanılacak sistemi kurmaya çalışıyorlardı."

${ }^{11}$ Staatssicherheit: Doğu Alman gizli polisi.

12 “Asıl adı Hector Lovell’dir.(s.274)”Pek çok takma isimle dünyanın değişik yerlerinde entrikalara katılmış ve bazı ayaklanmaları organize etmiştir. Doğu Blok dağıldıktan ve iki Almanya birleştikten sonra işsiz kalmış. Bir süre diğer Doğu Almanlar gibi bisiklet fabrikalarında montaj işçisi olarak çalışmış. Oysa o zamanki rütbesi binbaşıymış. Daha sonra şansını Makedonya'da denemek istemiş. Bir süre ortadan kaybolmuş. Kim ona daha fazla para verirse onun için çalışmaya başlamış."(s.325)

${ }^{13}$ Melody Duncan’ın öldürülme nedeni; onun elindeki bazı arkeolojik belgelerdir.(s.256)
} 
şirketlerine değişik ebatta uçak satan" Calliope Aerospace Industries, şirkete "internet çıkışlarının yavaşladığını ve network trafiğinin anlamsız bir şekilde yoğunlaştı̆̆ını bildirir." Timur, başlangıçta GhostWall'da bir problem olduğunu düşünür.(s.286,301) Ancak sorunun kaynağının, sisteme sızan ve tıpkı Stealth uçaklar gibi kendini bir şekilde görünmez yapmayı başarabilen bir "Truva atı" olduğunu keşfederler. Sealth, nasıl orada olduğu halde, radarda görünmüyorsa, bu kötü amaçlı yazılım da antivirüs programları ve sistem monitör yazılımları tarafindan, orada olduğu halde algılanmamaktadır.(s.290) Arsen keşfettiği bu "Truva Atı"na "Araknid” ismini vermiştir.(s.295) "Truva Atı"nın çalışma prensibi şöyledir: Sisteme "bir kere sızdıktan sonra sistem yöneticisinin şifresini girmesini bekliyor ve tuş basımlarını kaydedip şifreyi allyor. Daha sonra da admin şifresiyle, GhostWall'da gedik açıyor ve sistemdeki bilgileri aktartyor."...(s.297) Calliope Aerospace Industries'in gizli bilgileri, bu şekilde rakiplerinin eline geçmiştir. Patron Ray Scott, Arsen Bora ve Timur Sarp'tan çalınan bilgilerin geri alınmasını ister. Arsen duydukları karşısında irkilir, çünkü işleri güvenliği sağlamaktır, oysa Mr. Scott, onlardan hacker ${ }^{14} 1 \mathrm{k}$ hatta craker ${ }^{15}$ lik yapmalarını istemektedir.(s.312,315) Arsen, Mr. Scott'un bu isteğini başlangıçta reddeder ancak Mr. Scott, Arsen'in, istediklerini yapması karşıllı̆ında Melody’yi kimin öldürdügünü bulmasına yardımcı olabileciğini belirtir. Karısını öldürenlerden intikam almayı isteyen Arsen, Mr. Scott'un teklifini kabul etmiştir.(s.317) Arsen çalınan bilgileri geri almanın daha ötesinde bir formül düşünür ve onlara yanlış bilgi seti sunmaya karar verir. Böylece onlar elllerindeki bilgilerin hangisinin gerçek olduğunu anlayamayacak; hatta ellerindeki bilgilerin doğruluğuna inanmak, onlara pahalıya mal olacaktır.(s.318)

Calliope'deki saha ajanlarından gelen imdat mesaj1, Vulkan Sistemi'ndeki mentorlardan biri tarafından incelemeye alınır. İlk defa bir saha ajanı imdat mesajı yollamıştır. Ancak mesajı yollayan saha ajanıyla iletişime geçilememiştir. Bunun üzerine sisteme başka saha ajanları yollanır, fakat bu ajanlar da sisteme girmeyi başaramaz. Sorunun kaynağının Calliope'nin sisteminde kurulan "GhostWall" olduğu tespit edilir. Ateşduvarı, sistemi dışarıdan girişlere koruduğu gibi saha ajanlarını da yok etmektedir. Vulkan Sistemi'nin incelemelerinde göre GhostWall'la birlikte yazılımın üreticisi ARTIM teknolojileri'nin tehdit katsayısı $0,117^{\prime}$ 'den 0,328'e yükselmiştir. 0,300'lük bir katsayı harekete geçilmesini gerektirmektedir. Yollanan saha ajanlarıyla sisteme girmek mümkün olmadığından GhostWall yazılımının kodlarını elegeçirmek için ARTIM'a bir ekip yollama kararı alınır.(s.329-330) Yollanan ekip ARTIM'a saldırarak "bütün sunucuların sabit disklerini ve yedeklerini” çalar.(s.335)

Bu arada Pluto'nun sistemine sızma girişimleri yapılmaktadır. Bu saldırının Calliope Aerospace İndustries’teki bir sunucudan geldiği belirlenir. Bunun üzerine oldukça sinirlenen Concord, Pluto ekibinin tam kadro bulunduğu bir toplantıda; Pluto'nun gizliliğinin tehlike altında olduğunu ve bunun için ellerini taşın altına sokma zamanının geldiğini belirtir. Yani "artık birkaç can yakma zamanı gelmiştir..." Concord; "Bir an önce Calliope'nin "bize herhangi bir tehdit oluşturabilecek bütün imkânlarını yok etmenizi istiyorum.” diyerek Pluto'nun gizliliğini tehlikeye sokacak olmasına rağmen Calliope'ye düzenlenecek bir operasyonun emrini verir.(s.342-343)

Calliope'ye yapılacak operasyon için Mark Flexner ve yanındaki on iki adamı görevlendirilir. Hepsi iyi yetiştirilmiş uzman askerlerdir. Orduyla ilişkileri kalmadığı halde asker kimlikleri halen devam etmektedir. Plana göre, operasyon Elbe Nehri'nin yüzeyinden yedi metre kadar aşağıda bulunan Calliope'nin arıtma tesisinin kanal çıkışından yapılacaktır. Amaçları iletişim ve enerji altyapısını yok etmektir.(s.352-356) Bu iş için şirkette belirlenen yerlere beş bomba yerleştirilir. Keskin nişancı ekibinin

\footnotetext{
${ }^{14}$ İzinsiz olarak başkasının bilgisayarına girip işlem yapan kişi.(s.315)

${ }^{15}$ Başkalarının bilgisayarlarına girebilmek için program yazan kişi, kod kırıcı.(s.315)
} 
lideri Tracy Fox ise Raptor gece görüş dürbününün takı1ı olduğu M600 keskin nişancı tüfeğini yaklaşık altı yüz metre uzaklıktaki uydu iletişim sistemine yönlendirmiştir. Niyetleri bu sistemi yok etmektir.(s.361) Operasyonun başlama emiri verilmesiyle birlikte meydana gelen beş patlamanın akabinde komplekste tüm elektirikler kesilmiştir. Flexner ve ekibi şiddetli bir direnişle karşılaşır. Çatışma bir müddet sürer. Çok sayıda ölü ve yaralı vardır. Flexner dahil timden hiçkimse kendilerini kurtarmak için gelen helikoptere binememiştir. Yalnızca iki keskin nişancı helikoptere binerek kurtulmayı başarır. Arsen bu çatışmadan da sağ olarak çıkar. Ancak Pluto'nun elindeki iki ayrı rapor onun öldüğ̈̈ yönündedir.(s.361-367, 503)

Arsen, arkasında bir yapay zekâ teknolojisi olan "Araknid"leri bularak birilerinin tekerine çomak soktuğunun farkındadır. Böylesine gelişmiş bir teknolojinin çözümlenmesi ve arkasındaki yapının deşifre edilebilmesi için derhal Arsen'e yardım edecek bir takım oluşturma girişimlerine başlanır. Alan Vignette, Timur'a bu iş için yapay zekâ üzerine önemli çalışmalar yapmış olan ve halen Helsinki Üniversitesi'nde yapay zekâ ile ilgili bir projede çalışan Desiré Virtanen'in dosyasını vermiştir. Profesörün kendilerine Araknid'ler konusunda yardımcı olabileceğini düşünmektedirler.(s.336-337) Ancak öncelikle hangi tarafta olduğunu öğrenmek için bir süre Virtanen'i takibe alırlar. Bu arada Pluto, profesörü bir tehdit olarak gördüğü için ona nano enjeksiyon yaptırmıştır. ARTIM teknolojileri için çalışan takip ekibi, Virtanen'i acilen MR cihazına sokarak hayatını kurtarır.(s.389,439) Takip ekibinden Hild Erke, henüz hiçbir şeyden haberdar olmayan profesöre bazı bilgiler ile Timur Sarp ile görüşmesi için şifreli görüşme yapan bir de telefon verir. Virtanen verilen bu telefonla Timur Sarp ile görüşür ve Timur, kendisine ortak düşmanlarına karşı işbirliği yapmak istediklerini ifade ederek onu Türkiye'ye davet eder.(s.387-401) Profesör ayrıntıları konuşmak üzere, can güvenliği açısından Suvi Säde adına alınmış sahte bir pasaportla Antalya'ya gelir. Antalya'nın Kemer ilçesindeki bir otelde yapılan toplantıda Virtanen'e ortak düşmanları hakkındaki istihbarat bilgileri sunulur ve olayların iç yüzü anlatılır. Planları; düşman hakkında mümkün olduğunca bilgi toplayarak ondan zarar gören kişi ve kurumlarla bu bilgileri paylaşmaktır. Böylece başkalarının ellerinde bulunan güçleri de kullanarak düşmanlarına galip geleceklerdir. Düşmanı deşifre edebilmek için yapay zekâ ürünü yazılımlar tarafından çok iyi korunan sistemlerinde gedik açıp sahip oldukları kaynaklara ulaşmayı hedeflemişlerdir. Bunun için yapay zekâ alanında uzmanlaşmış olan Profesör Desiré Virtanen'e ihtiyaçları vardır. Virtanen kendisine yapılan işbirliği teklifini kabul eder. Ayrıca Timur, profesöre kendi yapay zekâ ekibinden Laina Vaara ve Rieti Paju dışında istediği kişiye yapacakları işle ilgili teklif götürebileceğini belirtir. Rieti sakıncalıdır çünkü CIA için çalıştığı tespit edilmiştir.(s.435,447) Virtanen takımdan yalnızca, yazılım ekibinin başında bulunan Lee Wong'u seçmiştir.(s.455) Ekip güvenlikleri için çalışmalarını Ege'de bulunan bir adada yürütecektir.

Adada zaman kaybetmeden çalışmalara başlarlar. Bu çalışmalar sonucunda çok önemli bilgilere ulaşmışlardır. Adaya sonradan gelen Timur'un "operasyon merkezi” adını verdiği bir çalışma odasında yaptıkları toplantıda gelişmeler şöyle anlatılmaktadır:

- "Bu odadaki altı kişi, ortak bir düşmana karşı savaşmak amacıyla bir araya geldi. Bundan birkaç yıl önce Mauno Lehtinen adında biri yapay zekâ yazılımlarını konu alan bir proje için sponsor arlyordu. Projesi için sponsor buldu ve çalışmaya başladl. Ağustos 2004 'te proje sonuçlanmak üzereyken, sponsorları ondan projeyi gizli tutmasını istediler. Amaçları projede elde edilen bilgileri sadece kendi çıkarları için kullanmak ve dünyayla paylaşmamakt. Fakat Lehtinen'in amacı para kazanmak değil, hayalinin gerçekleştiğini görmek ve bunu dünyaya sunmaktı. Bu gruba karşı çıkan Lehtinen, nano enjeksiyonla öldürüldü, Helsinki Üniversitesi’ndeki çalışmaları çalındı. (...) Profesör 
Lehtinen, projenin başına gelebilecekleri tahmin edebilmiş ve projenin bir kopyasını Desiréye yollamıştı. Desiré projeye devam etme kararı aldı."(s.468)

- "Zor günlerdi, ama atlattık. Mauno için projeyi bitirme kararı almıştık. Yeni sponsorlar aramaya başladık. Görüşı̈̈̆̈̈̈müz kişiler ilk başlarda projeyle ilgileniyorlardl, fakat daha sonra da caylyorlardı. Birkaç ay bulmaya çalıştık. En sonunda bir vakıf bize destek olmaya karar verdi ve rölantide giden çalışmlarımız hız kazandı. Dağılan ekibin büyük çoğunluğunu tekrar projeye aldık ve çalışmalara başladık. Birkaç aylık gecikmeyi saymazsak projeyi zamanında bitirdik.”(s.470)

- "Bu vakfi CIA'in kontrol ettiğini öğrendik. CIA, gelişmekte olan ülkelerdeki bazı aktivitelerinde bu vakfı kullanıyormuş. Dışarıdan bakıldığında vakfın bütün faaliyetleri normal. Ama faaliyetlere verilen izinler CIA tarafından onaylanıyor. (...) Edindiğimiz bilgiye göre, projedeki bütün aşamaların bir kopyasını almışlar.”(s.470)

- "Dün gece altı saat boyunca, düşmanımızın geçmişini araştırdım. Tahminlerimin aksine, geçmişleriye ilgili bilgilere ulaşmak çok zor oldu. Kendi sistemlerinde kendileriyle ilgili bilgi bulunmuyor. Çok az şey bulabildim. Bulabildiğim kadarıyla, XVI. Yüzyılda denizaşırı ticaret yapan bir grup tüccar, gemilerine yapılan korsan saldırılarına karşı biraraya gelmeye karar vermişler. Altı tüccar ve iki armatör kendilerini ve çıkarlarını korumak için bir birlik kurmuşlar. Örgütlerine de Latince'den kaba bir çeviriyle, 'gölge denizci' anlamına gelen, "Umbranaut" adını vermişler. (...) Bu kelime üzerinde kapsaml bir arama yaptım internette. Ama pek dişe dokunur bir bilgi elde edemedim. Anladığım kadarlyla bu sekiz aile, değişen dünya şartlarına ayak uydurmuş, tüccarlığa ek olarak önce koloniciliğe, sonra bankacıllğa, çelik ve silah üretimine girmişler. En son olarak da kömür madenleriyle enerji sektörüne girmişler. Şu anda ne yaptıklarını bilmiyorum, ama dünyanın en zengin ilk yüz ailesi içinde onların olduğunu ögrrenirsem hiç şaşırmam. "(s.473)

Alan Vignette çok iyi bir araştırmacıdır. Araknid'i gönderen sunucuyu bulduklarında, Alan, GORI'nin adıyla ortaya çıkmış ve saldırıyı GORI'nin yapmış olabileceğini söylemiştir. Bundan bir gün sonra da Arsen, Araknid'ler ile GORI arasındaki ilişkiyi keşfetmiştir. Vignette'in elindeki bilgilere göre GORI, kompleks eski bir nükleer yeraltı silosunun üstünde kurulmuştur. Ve GORI buzdağının sadece üst kısmıdır...(s.350-351) Adada yürütülen çalışmada GORI'nin altında bulunan Pluto'nun içine sızmayı başarırlar. Bu arada Umbranautlar'ı da keşfetmişlerdir.(s.468) Bunu Araknid'ler üzerinde çalışıp onları kontrol edecek modüller hazırlayarak yapmışlar ve daha sonra kendi hazırladıkları Araknid'leri Vulkan Sistemi'ne yollamışlardır. Sisteme sızdıklarında görmüşlerdir ki yapay zekâ sistemleri enstitüden çaldıkları sistemle aynıdır. Sistem yönetim yazılımlarını incelemeye alıp "onların mentor adını verdikleri karar verici ajanlardan birini” kendi yapılarına aktarırlar. Sistemin hem üst karar mercii olan hem de tüm sistemin kontrolünü sağlayan BlackBox adı verilen sistemin içine girmeyi başaramazlar. Ancak Vulkan Sistemi'ndeki yapay zekâ yazılımlarını kendi hazırladıkları ve Suvi-X adını verdikleri melez yazılımla değiştirmişlerdir. Böylece BlackBack'ın Vulkan Sistemi üzerinde hiçbir kontrolü kalmadığı gibi bütün kontrol onların eline geçmiştir. Sonunda Pluto'nun tüm veri ambarına müdehale ederek Calliope'den çalınan bilgilerin tümünü geri almayı başarırlar.(s.476-477)

Arsen bundan sonra eşi Melody'yi öldürenlerden intikam almak için çalışmalara başlayacaktır. As1l hedefi Umbranautlardır. Ancak ellerinde onların kim oldukları hakkında bir bilgi yoktur. BlackBox karar verici son mercii olduğuna göre bu yapının Umbranautların bilgisine sahip olduğunu düşünürler. Çünkü BlackBox bu bilgiye sahip olmasaydı, Vulkan Sistemi'nin Umbranaut'ların çıkarlarına aykırı bir operasyon yapma ihtimali çok yüksek olurdu... Kafalarındaki bu güçlü ihtimal onların yeni bir fikir geliştirmesini sağlar. Buna göre "şirketlerin, bilgisayar sistemlerine Araknid yollamak için Blackbox'tan izin isteyecekler ve izin vermedikleriyle ilgileneceklerdir."(s.480-483) 
Sarah Concord'u sinirlendiren önemli gelişmeler olur. "Son iki gün içinde, Umbranautların çıkarlarına on beş kez saldırılmış, doksan iki kişi tutuklanmış ve yirmi üç kişi de ölmüş" böylece gizliliği birinci ilkesi olarak kabul eden Umbranautlar deşifre olmuştur. On altınc1 operasyon FBI Başkan Yardımcısı Daniel Samuel ve FBI'daki ekiplerine karşı yapılmıştır. Operasyon sonunda yirmi bir kişi tutuklanır ve dört kişi de ölü ele geçirilir. "Birileri Pluto'nun ünitelerine en fazla zarar verebilecek düşmanlarını bulup onları bilgilendirmektedir"... Bütün ekiplere kamuflaj emri verilmiş, tam bir savunmaya çekilmişlerdir. Saldırılar karşısında sessiz kalmak dışında bir şey yapamamaktadırlar. (s.485-486) Concord kendisinin vermesi gereken kararları makineler verdiği için "içi saman dolu bir kukla" gibi olayları izlemek zorunda kalmıştır. Ancak o, kozalarına çekilip beklemek yerine "karar verme işini üzerine almak" niyetindedir."(s.484-485)

“İkinci Dünya Savaşı'ndan beri ilk defa Umbranautlar, kabuğa çekilme aşamasına bu kadar yaklaşmıştı. Hiçbir simülasyon böyle bir kabuğa çekilme aşamasına gelinebileceğini öngörmemişti. Ortada elle tutulur hiçbir neden yoktu. Ortada düşman bile yoktu. Ama saldırllar o kadar değişik kaynaklardan geliyordu ki, arkasında nasıl bir gücün olduğunu hayal edemiyordu. Bütün olasıllkları düşünmüştü. Dünya çapında bu kadar büyük bir operasyonu eşzamanlı olarak başlatabilecek hiçbir güç yoktu. Bunu ancak Vulkan Sistemi başarabilirdi... (...) Birileri Vulkan'ın içine sızmış olmalıydı ... Başka hiçbir güç bu kadar organize bir saldırıyı planlayamazdı."

Vulkan Sistemi'ne tehdit oluşturabilecek üç kurum vardır. İlk sıradakiler NSA ve CIA'dir. Üçüncüsü ise Calliope olarak gözükmektedir. CIA ve NSA'nın böyle bir saldırı planlamak yerine, doğrudan Pluto'ya saldıracaklarını tahmin ettiklerinden Calliope şirketi üzerinde durmaya karar verirler.(s.501) Concord kendisine verilen bazı bilgilerden hareketle Calliope, ARTIM ve Profesör Desiré'ın birlikte çalışıyor olabileceğini düşünür. Sezgileri kuvvetli olan başkan, Arsen Bora'nın yaşadığına inanmaktadır.(s.506) Bu nedenle Calliope'nin sahibi Ray Scott, Desiré Virtanen ve Arsen Bora'nın saf dışı edilmesi için bir operasyon başlatır.(s.513)

$\mathrm{Bu}$ arada saha ajanlarından aldıkları bilgilere göre CIA başkan yardımcılarından Stan Nick tutuklanmış ve CIA'deki ekip dağılmıştır.(s.513) Ayrıca BlackBox’tan da çeşitli operasyon emirleri gelmektedir. Karşı operasyonlar devam etmektedir. Önemli bir gelişme daha olmuş, BlackBox'tan gizlilik kodu çok yüksek olan bir mesaj alınmıştır. Mesaja göre; Umbranautlar, yarın sabah sekizde Pluto'ya geleceklerdir.(s.513-516)

İpek atkılarının sol ucunda kanatlı bir gemi resmi olan yedi Umbranaut toplantı odasına gelir. Bir süre toplantı gündemi hakkında konuşurlar. Arsen, "kendilerini insanlı̆̆ın ve hukukun üzrerinde gören" bu insanlardan intikam almak için onları öldürmeye karar vermiştir.(s.527) Çaresiz olanlar bu defa kendi çıkarları için birçok masum insanı öldüren Umbranautlar'dır... Arsen, aniden toplantıya bilgisayarıyla bağlanır ve buna çok şaşıran gruba niyetini ve kendilerini öldürmek için yaptı̆̆ 1 planı anlatır. Ray Scott bu plana karşı çıkar. Çünkü Calliope'in başkanı Ray Scott hem saygın bir işadamıdır hem de Amerikan Hükümeti'nin ulusal güvenlik danışmanı olan babası Greg Goldsmith bir Umbranauttur. Bu sırada patronunu korumak için Arsen'e silah çeken Alan Vignette, Timur tarafindan öldürülür.(s.537) Pluto’ya girişte, el izlerini okuturken tüm Umbranaut'lara nano enjeksiyon yapılmıştır. Ray Scott da nano enjeksiyondan payını almıştır. Tüm bu olanlardan sonra Arsen ve Timur volkanik kayalıklara kurulu şatodan çıkıp adadan ayrılır. Nano enjeksiyon yapılan herkes en korkunç kabuslar ve halüsinasyonlar eşliğinde ölürler.(s.547-557) 


\section{“Kuantum Şifresi” Romanında Halüsinojenlerin Enjeksiyon Yöntemiyle Kullanımı}

GORI'nin başkan yardımcısı Sarah Concord, "NSA'nın içinde bir operasyon başlatarak" proje ekibinden “Kuantum Kripto Projesi”nin direktörü Fitz Patrick Garner'nn ve "projenin birinci aşamasının tamamlanmasını" sağlayan Arsen Bora'nın öldürülmesi emrini vermiştir.(s.52-53) Lil Sutack, Garner'1 ortadan kaldırmak için onu takip etmiş, eve dinleme sistemi yerleştirmiş ve Meade Golf Kulübü’nde ona “nano enjeksiyon” yapmıştır.(s.17)

'Lil Sutack, 'Meade Golf Kulübü'nden çıkarken Garner'a çarparak yere düşmüştü. Yüzüğ̈̈nün içinde bulunan zehri nano enjeksiyonla, kendisini kaldıran Garner'ın ensesine yapmıştı. Garner hiçbir şey hissetmemişti; oysa vücuduna, enjeksiyon anında aktive olduktan sonra durdurulmast imkânsı iki grup nano makine enjekte edilmişti. Nano enjeksiyon, tam bir suikast silahı olarak tasarlanmıştı. Amacı kurbanı öldürmek ve bu arada suikastçıya zaman kazandırmaktı. İki grup nano makine kurbanın bedenine giriyor, birinci grup kurbanın bilinçaltında yaşattığ en korkunç kâbusları ortaya çıkarıyor, kurbanına on iki saat boyunca şiddetli sanrılar gösteriyordu. Ölümcül değildi. Amacı kurbanın çıldırmasını sağlamak, bir şekilde kendini öldürmesini veya öldürülmesini teşvik etmekti. İkinci grup nano makineler ise aktif hale geçtikten bir buçuk saat sonra, kurbant iki saniyede öldüren ikinci zehri kurbana enjekte ediyordu. Ikkinci grubun amacı, kurban yarım saat içinde ölmemişse, sessizce ölümünü sağlamaktı. İki zehrin de, bilinen bir panzehri yoktu. Nano makineler öyle programlanmışlardı ki, kurban ölse dahi durmuyorlar, görevlerini sonuna kadar yapıyorlardı. Bir kez aktif hale geçtikten sonra, durdurulmalarına imkân yoktu."(s.22) "Nano enjeksiyon, çok iyi korunan devlet adamlarına suikast düzenlemek amacıyla geliştirilmişti. Devlet adamına uygun bir zamanda yapılacak minik bir temas sayesinde, bir süre sonra ölümüne neden olabileceklerdi. Nano makinelerin üretimleri sirasinda, içlerindeki zehri vücuda zerk edecekleri zamanları değiştirilebiliyordu. Bu şekilde aylarca sonra zehrini enjekte edebilecek nano makineler yapmak mümkündü. Genel olarak kullanılan süre Amanita Panterina için bir saat ve Conticeo için ise bir buçuk saatti. Her iki zehrin de otopside çıkması mümkün değildi.”(s.57)

Garner'ın babası Hitler rejiminden kaçmış olan Alman kökenli bir bilim adamıdır. Savaş daha başlamadan Fransa'ya oradan da İngiltere'ye kaçmıştır. Savaş başlayınca İngiliz kod kırıcılarının merkezi olan, Bletchley Park'ta altı yıl kadar çalışmıştır. "Almanların Kreigsmarine Enigma M3 adll, Alman Deniz Kuvvetleri şifresini çözen" ekibin içinde yer almıştır. Garner yirmi beş yaşına kadar babasının matematik profesürü olduğunu düşünmüş, babasının bilinmeyen geçmişini ancak o yaşta öğrenebilmiştir.(s.18) Garner'ın sanrıları kendi ailesi ve siyasi geçmişe yöneliktir:

"Garner elinin tersiyle gözlerini ovalad, ama işe yaramadı. Sanki ya geçmişi siliniyor ya da geçmişe dönüyordu. Bir zaman tüneli açılmış, (...) babasının gençlik çağlarına doğru bir yolculuğa başlamıştı. Odayı kaplayan müzik değişmeye başladı. Katie Webster'ın sesi pesleştikçe, arka plandaki tiz sinyal sesleri artmaya başladl. Müzik setine baktt. Bir şeyler oluyordu. Birden müzik setinden gelen sesler, kulağı tırmalayan radyo sinyallerine dönüşü. Sanki tranzistorlu bir radyonun başındaydı ve sürekli bir istasyondan diğerine geçerek radyoyu kurcallyordu. Bir süre, birinden diğerine gidip geldikten sonra, yayın bir istasyonda sabitlendi. Biri Almanca konuşuyordu. Ne söylediğini anlayabilmek için tüm dikkatini konuşmaya verdi. (...) Nasıl olup da o sesleri duyduğunu sorgulamak, aklının ucundan geçmiyordu. (...) Biri nutuk çekiyordu ama, sesler bir tünelin ucundan geliyormuş gibi, uzak ve ekoluydu. Radyodaki sesi bir yerden tanıyordu, ama nereden olduğunu çıkaramıyordu. Konuşmanın arka planında, mors koduyla bir mesajın yollandı̆̆ına dikkat etti. Bir yandan konuşma, diğer yandan radyodan yollanan mors kodu, zihninde imgeler halinde belirmeye başladl. Sanki beyni birdenbire 
normalin on katı kapasiteyle çalışıyordu. Hatta, belki de yüz katı... Bir anda ne olduğunu anladı. Amerika'nın işgalinin her aşaması, beyninin içinde cisimleniyordu. Annesinin İkinci Dünya Savaşı 'yla ilgili anlattı̆̆ anıları gerçek oluyordu. Çok geçmeden hava saldırısının başlayacağını düşündü. Belki de çoktan başlamıştl. (...) Radyoda verilen steganografik mesajlara odaklandl. (...) Radyodaki yayın tekrar değişti ve başka biri konuşmaya başladı. Başlangıçta ses zayıftt. Bu sesi de bir yerden tanıyordu. (...) konuşan babasıydl. Evlat, ülken için bir şeyler yapma zamanın geldi... Birazdan benim de yerimi bulacak... Ses kesildi. Istasyon arama sesleri tekrar duyuldu. Baba! Baba! Garner çılgına dönmüştü. (...) Duyduğu seslerin tümü zihninde görüntüler halinde beliriyordu. Dünyantn değişik yerlerindeki olayları radyo yayını aracılı̆gyla görüp, konuşmaları duyabiliyordu. Bütün dünyanın bilgisi ona gelirken, dünyayı tehlikeden korumak için yapabileceği hiçbir şey yoktu. İ̧̧inde bulunduğu durum Truvalı Kassandra'nınkine çok benziyordu. Her şeyi görüyordu, fakat insanları olan bitenlere nasıl ikna edecekti?"(s.18-20)

Kanına karışan zehir Garner'ın bilinçaltındaki en korkunç kabuslarını ortaya çıkarmış ve sanrılar görmesine neden olmuştur. Gerçekle hayal dünyası arasındaki sınırlarda dolaşmakta olan kahraman kendi korkularından oluşan bir hayal sarmalı içinde, yaşadıklarından hangisinin gerçek hangisinin hayal olduğunu ayırt edecek durumda değildir.(s.21-22) Yaşadığı kötü deneyimden dolayı kendini savunma ihtiyacı hissettiği için eline aldığı Wesson 380'lik tabancasıyla penceredeki gölgeye doğru ateş etmeye başlayan Garner, polislik yapan Çavuş Jason Mender'i kasığından yaraladıktan bir süre sonra öfkeli polisler tarafından yaylım ateşine tutularak öldürülür.(s.22-25,56)

Projenin tehdit katsayısını düşürmek için projede görev alan Marco Marconi’nin de tıpkı Garner gibi saf dışı bırakılması emri verilmiştir. Marco Markoni projenin birinci aşamasının bitiş kutlamaları için cumartesi gecesini ayarlamıştır. Kutlamadan sonra Laura Hayes, Murphy's Irish Pub'a gitmek ister. Laura kağıt üzerinde evlidir. Yani kocasıyla hiçbir ilişkisi yoktur. Bu durum onların birlikteliklerine engel değildir.

Mekanın çıkışında mavi elbiseli bir kadın onlara fark ettirmeden nano enjeksiyon yapmıştır. Ölüm listesinde ismi olmayan Laura Hayes da Marco ile birlikte olduğu için nano enjeksiyona maruz kalır. İki sevgili aynı arabanın içinde yapılan nano enjeksiyonun etkisiyle can verirler.(s. 63-79) Ölümleri şöyle gerçekleşmiştir:

"Marconi bir an kendinden geçer gibi oldu. Aynadan gelen lşık gözlerini alınca kendine geldi. Arkadaki arabanın aynadan yansıyan ışı̆̆ı beynini yakıyordu. "Aman Tanrım, gelen nedir öyle?” dedi. (...) Laura bir an için ne olduğunu anlayamadı. (...) Bütün duyuları aşırı hassaslaşmıştı. Marco, (...) "Merak etme, bizi yakalamalarına izin vermeyeceğim aşkım!" diye bağırdı. (...) Zehir Laura'yı da etkilemeye başlamıştı. Elinde olmadan emniyet kemerini gevşetip, arkalarındaki ışığa baktt. Zehrin etkisiyle büyüyen gözbebekleri, ışığa reaksiyon verip küçülmedi. Işsk neredeyse gözlerini kör edecekti. (...) Arkadaki arabayı ve direksiyondaki kocasını görebiliyordu. Yanındaki koltukta ise annesi vardı. Oysa annesi öleli sekiz yll olmuştu. 'Kocam! Bizi takip etmiş olmalı!' (...) Ben seni korurum aşkım dedi Marco. Her ne pahasina olursa olsun Laura'yı koruması gerekiyordu. Vitesi küçülttü ve gaz pedalına köküne kadar bastı. (...) Ayağını gazdan çekmeden, ışıklara doğru arabasını sürmeye başladı. Ne de olsa artık onlar da ışıktı. (...) Araba, kirmızı bir alev yumağı halinde bir süre gittikten sonra yolun kenarında durdu. Alevlerin yerini, yer yer kömür siyahı duman almıştı. Patlayan benzin deposundan çevreye yayılan benzin ise yolun üzerinde pirlltılarla yanıyordu."(77-78) 
Walltrip emekli olunca Pluto'nun başına Sarah Concord geçer.(s.101) Concord'un Arsen Bora'ya yönelik düşünceleri değişmemiştir. Onun bir gün başlarına bela olacağını düşünmektedir.(s.104) $\mathrm{Bu}$ yüzden Pluto'nun yeni başkanı, 11 Eylül saldırılarından sonra İstanbul'a dönen Arsen Bora'yı ve eşi Melody Duncan'ı ortadan kaldırma konusunda kararlıdır. Bu iş için eski Stasi ajanı Markus Ludwing ve yanında dört kiş̧iyi daha görevlendirir. Ludwing'in yanında seçilenler, Hollanda gümrüğünde 250gr uyuşturucuyla yakalanan bir mafya grubudur.(s.133,139) $\mathrm{Bu}$ grup içinde Metin Karakul ve Osman Selence eski birer teröristtirler. Bekir Turan ve Hamit Erduru ise mafyayla ilişkileri nedeniyle çevik kuvvetten atılmışlardır.(s.133) CIA'in bölge şef yardımcısı Julius McGinley gümrükteki mallarının kurtarılması karşılığında, bu adamları evli çifti öldürmeleri için ikna eder.(s.141) Melody öldürülür ancak Arsen Bora'yı öldürmeyi başaramazlar. Ludwing, Metin Karakul'u ortadan kaldırmak için nano enjeksiyon yapmış, çatışma sırasında Metin Karakul'un ortağı Osman Selence ve diğer iki adamı; Bekir Turan ve Hamit Erduru, Arsen Bora'nın Hammerli 208'inden çıan kurşunla öldürülmüştür.(s.186,187)

Pluto, verilen görevi başaramayan Ludwing'i öldürmek için dört tetikçi yollamış, eski Stasi ajanı dördünü de saf dışı bırakmıştır. Ancak Ludwing, Arsen Bora için aktif hale getirdiği iğneyi yanlışlıkla kendi bacağına batırınca "yüzüğün içindeki yüzlerce nano makine vücudunun içine girer". Bu arada Timur, arkadaşı Arsen'i korumaya çalışırken Ludwing'in nano enjeksiyon iğnesine maruz kalmıştır.(s.258). Okul yıllarında nano enjeksiyonla ilgilenmiş olan Arsen, MR cihazının güçlü manyetik alanından yararlanarak Timur'un vücuduna sızmış olan nano makinelerin programlarını bozmayı başarır.(s.266) $\mathrm{Bu}$ arada Ludwing camdan atlayıp intihar eder.

Mauno Lehtinen adında bir profesör yapay zekâ yazılımlarını konu alan bir proje için sponsor aramaktadır. Projesi için sponsor bulur ve çalışmaya başlar. Ağustos 2004'te proje bitmek üzereyken sponsorlar ondan projeyi gizli tutmasını isterler. Amaçları projede elde edilen bilgileri yalnızca kendi çıkarları için kullanmak ve bunu dünyayla paylaşmamaktır. Fakat Lehtinen'ın hayali para kazanmak değildir. Onun amacı hayalinin gerçekleştiğini görmek ve bunu dünyaya duyurmaktır. Bu gruba karş1 çıkan Lehtinen, nano enjeksiyonla öldürülür ve Helsinki Üniversitesi'ndeki çalışmaları da çalınır. Profesör Lehtinen, projenin başına gelebilecekleri tahmin ettiği için projenin bir kopyasını aynı projede çalışan Profesör Desiré Virtanen'e yollamıştır. Desiré projeye devam etme kararı alır. Birkaç aylık gecikmeyle projeyi zamanında bitirirler. $(\mathrm{s.468,470)}$

Profesör Mauno’nun ölümü şöyle gerçekleşir:

Mouno ailesiyle yemeğe limana gider. Yemeğe başladıktan kısa bir süre sonra da garip davranışlar sergileyerek, etrafa saldırmaya başlar. Hatta karısını ve kızını itip restorandan koşarak çıkar. Peşinden koşmaya başlarlar, ancak Mauno iskeleden denize atlar ve denizde kaybolur. Birkaç dakika sonra iki tekne, onu aramaya başlar ve mendireğin hemen dışında ona ulaşıp tekneye alırlar, fakat ambulansla hastaneye kaldırılırken yolda ölür.(s.278) Ölümünden sonra gazetelere "Kaçık Profösörun Sonu" diye başlıklar atılır. "Herkesin onu yapay zekanın Don Kişotu olarak görmesine ragmen, Mauno Lehtinen asla bir kaçık değildir. Ömrünün hiçbir anında aklı başından” gitmemiştir.(s.278)

Pluto, Profesör Desiré Virtanen'i da bir tehdit olarak gördüğü için ona nano enjeksiyon yaptırmıştır. ARTIM teknolojileri için çalışan ve onu takibe alan ekip, Virtanen'i acilen MR cihazına sokarak hayatını kurtarır.(s.389,439)

"Desiré, mini arabasına bindi ve mutfak alışverişini yapmak için civardaki marketlerden birine doğru yola çıtıtı. On dakikalık bir yolculuktan sonra alışveriş merkezine ulaştı ve bir alışveriş arabası alıp, 
sebze bölümünün yolunu tutu. Arabasını tezgâhta bulduğu sebze ve meyvelerle doldurduktan sonra, ikinci dură̆ı olan içki bölümüne geçti. (...) Alışverişini bitirip kasaya geldiği zaman, çikolataların bulunduğu bölümdeki kadın dikkatini çekti. Ofisten çıkarken gördüğ̈̈ kadındı. Kadın yanındaki bir adamla konuşuyor gibi yapıp, gözünün ucuyla da onu takip ediyordu. Bütün benliğini kaplayan bir tedirginlikle sarsıldl. (...) Ensesinde başlayan ürperti omuriliğinden beline, oradan da kollarına geçmişti. (...) Kadın cep telefonuyla konuşuyor gibi yapıyordu. (...) Yüreği firlayacakmış gibi çarpmaya başlamıştı. (...) Birdenbire koşmaya başladı. (...) Bir an önce arabasına binip, uzaklaşmalıydı. (...) Koşarken çarptığı arabaların alarmları çalmaya başlamıştı. "Sesler ve ışıklar o kadar yoğundu ki. Sanki gözlerine bir mercek yerleştirilmişti ve bütün ışıklar yüz katı güçle gözbebeklerine doluyordu. Her şey birbirine girmişti. Bütün ışıklar ve sesler birbirine karışmıştı. Neyin ses, neyin ışık olduğunu bile algılayamıyordu. Sanki ışık huzmeleri binlerce iğneymiş gibi beynine batıyordu. [Sürekli birilerinin kendisini öldürmek istediğini haykırlyoru (s.378)](...) Desiré bir külçe gibi koltuğa ylğıldı. On iki saat boyunca yaşadığı halüsinasyonlar ve kendine gelmek için aldiğl ilaçlar, bütün gücünü tüketmişti."(s.346-348, 377)

Romanın son bölümünde Umbranautlar, Pluto'ya gelmiştir. Pluto'ya girişte, el izlerini okuturken tüm Umbranautlara nano enjeksiyon yapılır. Ray Scott da nano enjeksiyondan payını almıştır. (s.547-557)

Arsen yaşananları şöyle izah etmektedir: "Sizinki kadar büyük bir organizasyon sadece bir şekilde çökertilebilirdi. Biz de ne olduğunu bulduk. Sizin silahlarınızı size karşı kullandık. Çok gelişmiş bir istihbarat ă̆ınız vardı. İstihbarat ağınızı kullandık ve elde ettiğimiz bilgileri, düşmanlarınıza verdik. Kendi güvenliğiniz için kurduğunuz Pluto'yu mezarını yapmaya karar verdik. Şimdi gelelim nasıl öleceğinize... (...) Pluto'ya girişte, el izinizi okuturken hepinize nano enjeksiyon yapıld. Odada bulunanların içinde sadece Sarah Concord'a nano enjeksiyon yapılmadı. Sarah Concord için olası üç son var. Ya onu öldüreceksiniz ya ölene kadar Pluto'nun içinde hapis kalacak ya da intihar edecek."(s.547)

Tüm bu olanlardan sonra Nano enjeksiyon yapılan herkes en korkunç kabuslar ve halüsinasyonlar eşliğinde ölür.

\section{SONUÇ}

$\mathrm{Bu}$ makalede egemenlerin, toplumları yönetmek maksadıyla kullandıkları bazı zihin kontrol yöntemlerini 'Kuantum Şifresi' romanından hareketle işlenmeye çalışılııı̧̧ır. Birçok araştırmacının da ifade ettiği gibi iktidar özü itibarıyla baskıcı ve kıstlayıcıdır. Aynı zamanda kaostan beslenir. Düzeni sağlama maskesi altında toplumunsal zihin iktidar tarafından sürekli olarak dil, din, ırk, örf, adet ve bunun gibi birçok kavram kullanılarak dejenere edilir. Çünkü bu kavramların aşılandığı bireylerin yönetilmesi çok daha kolaydır. Beyni belli kodlarla yıkanmış bireylerin oluşturduğu toplumlarda dönemlere göre farklılık göstermek kaydıyla, spesifik bir grubun çıkarı bireysel çıkarlardan üstün tutulur. Oysaki genel anlamda bireylerin tek tek ihtiyacı, ki bu insan hakları kavramına denk düşmektedir, tüm toplumun güven ve hürriyetinin teminatıdır. Özgür bireylerden oluşan bir toplumda bir grubun iktidarı olmaz. Çünkü evrensel hukuku içselleştirmiş ve insan hayatına saygının gereklerini yerine getiren bu bireylerin oluşturduğu toplumlarda gruplaşmalar yaşanmaz bir bütünlük ve düzen meydana çıkar. Bu toplumlardaki tek iktidar hürriyetin sembolü niteliğindeki hukuktur. 
Düşmanını tanımadan onunla mücadeleye girişmek güçtür. $\mathrm{Bu}$ bakımdan insanlar, bireysel özgürlüklerini tehdit hatta yok eden sistemi iyi tanımalıdır. Bu maksatla eğitim ve öğrenim hayatı boyunca teferruatıyla hukuk, psikiyatri, teknoloji, beyin yıkama konulu derslere ağırlık verilmeli, eğitimin esas amacı bilimsel düşünüp sorgulayan, birbirlerinin hak ve özgürlüklerini gözeten, ruhen sağlıklı bireyler yetiştirmek olmalıdır.

\section{REFERENCES}

- Bahar, İ. (2009). İstihbarat Örgütlerinde Beyin Yıkama, İstanbul: Kumsaati Yayın Dağıtım Ltd. Şti.

$\bullet$

- Brown J.A.C. (2012). Beyin Yıkama, Çev. Behzat Tanç, İstanbul: Boğaziçi Yayınları A.Ş.

- Çebi, H. Y. (2012). “Zihinlere Tecavüz Edenler”, Zihin Kontrol Operasyonları, (Ed. Cem Küçük), İstanbul: Profil Yayıncılık.

$\bullet$

- Çimen, A. (2004). Kuantum Şifresi, İstanbul: Doğan Kitapçılık AŞ.

- Keith, J. (2006). Amerikan Derin Devleti ve Beyin Y1kama Operasyonları, Ankara: Nokta Kitap.

- Koşan, Ü. (2000). SESSİZ ÖLÜM Tabutluklar, Beyin Yıkama ve Tecrit Hücreleri, İstanbul: Belge Uluslararası Yayıncılık.

- Özkaya, Ö. (2013). Zihin Kontrol İnsan Beynini Kontrol Altına Alma Yöntemleri, İstanbul: Pegasus Yayıncıllk Tic. San. Ltd. Şti.

- Sayın, Ü. (2007). “Derin Devletler Gizli Projeler ve Kirli Gerçekler”, İstanbul: Neden Kitap Yayıncılık Hizmetleri.

-

- Şimşek, E. (2005). İstihbarat Servislerinde Beyin Yıkama Operasyonları, İstanbul: Kum Saati Yayıncilik.

- Victorian, A. (2007). İstihbaratta Beyin Yıkama Beyin Kontrolü, Çev. Mustafa Mencütekin, İstanbul: Timaş Yayınları.

-

- Yılmaz, S. 21. (2006). Yüzyılda Güvenlik ve İstihbarat, İstanbul: Alfa Basım Yayım Dağıtım Ltd. Şti.

- Yilmaz, S. (2014). ABD İstihbarat1 1947-2014, 2.bs., Ankara: Kripto Basım Yayım Dağıtım Ltd. Şti.

$\bullet$

- Yörükoğlu, T. (2012). İstihbarat Servislerinde Beyin Y1kama Operasyonları, İstanbul: Kumsaati Yayın Dağıtım Ltd. Şti. 